\title{
Palynological investigations at the Late Bronze-Early Iron Age lakeshore settlement of Luokesa 1 (Moletai District, Lithuania): a contribution to the Middle-Late Holocene vegetation history of the south-eastern Baltic regions
}

\author{
Annekäthi Heitz-Weniger
}

Received: 29 October 2013/Accepted: 28 March 2014/Published online: 18 April 2014

(C) Springer-Verlag Berlin Heidelberg 2014

\begin{abstract}
Today, the settlement site of Luokesa 1 (L1) lies under water at the northern edge of Lake Luokesa in the Baltic Uplands, south-eastern Lithuania. Its $60 \mathrm{~cm}$ thick Late Bronze-Early Iron Age cultural layer lies on top of lake marl. During excavations in 2008 and 2009, core samples at L1 were taken for the purpose of multidisciplinary investigations. From this material, five on-site pollen diagrams were created in parallel with geoarchaeological investigations and the examination of the botanical macro-remains. Two of these cores mainly comprised the cultural layer, another two consisted largely of the underlying lake marl and the fifth contained primarily the transition from the lake marl to the cultural layer. The chronological sequence was established through 11 AMS dates. The woodland history, starting from the Late Atlantic period, was recorded. The Quercetum mixtum values are quite low in the Subboreal, with the coniferous forest consisting mainly of Pinus and, though significantly less, Picea. At the transition to the cultural layer (Subatlantic) the pollen curves are highly variable, showing peaks in the curves for Betula and Alnus. Pollen from aquatic plants is also present. Changes in riparian vegetation and turbulent sedimentation conditions are to be expected and can be explained by a drop in the water level. As L1 was located on damp ground at that time, water influxes alternating with dry episodes were observed. In the area around L1 the sedge belt was less pronounced, and
\end{abstract}

Communicated by F. Bittmann.

A. Heitz-Weniger $(\square)$

Integrative Prehistory and Archaeological Science, Department

of Environmental Sciences, Basel University, Spalenring 145,

4055 Basel, Switzerland

e-mail: annekaethi.heitz@unibas.ch riparian woodland extended all the way to the shores of the lake. Pollen analyses of four sheep/goat dung samples provide information on the grazing season and pasture location of these domestic animals. The paper also discusses layer formation processes such as water level fluctuations and hiatuses.

Keywords Pollen · On-site investigation - Lake level fluctuation - Cultural layer - Riparian woodland · Human impact

\section{Introduction}

State of research and aims of the study

Lithuania consists mainly of plains and hills with elevations up to nearly $300 \mathrm{~m}$ a.s.l. The country has some 4,000 lakes, of which only 2,500 are larger than $0.01 \mathrm{~km}^{2}$. They are concentrated in the uplands and the south-eastern plain (Kabailiene 1996) and originated in the Late Pleistocene. The lakes often contain sedimentary sequences that date back to the Late Glacial period (Kabailiene 1998). Therefore, the area is ideally suited for the reconstruction of the Holocene vegetation history using palynological investigations. In particular, thanks to decades of pollen-analytical research in Lithuania by Meilute Kabailienè, a large number of pollen diagrams are available (Kabailiene 2010). This research dealt primarily with the creation of pollen spectra and their interpretation. This was carried out, using recent studies, to provide a basis for the evaluation of the pollen spectra. Due to the great number of pollen diagrams, the Holocene vegetation history of Lithuania is known and, accordingly, could be divided into chronozones (Kabailiene 1998, 2006a) that have also been confirmed more 

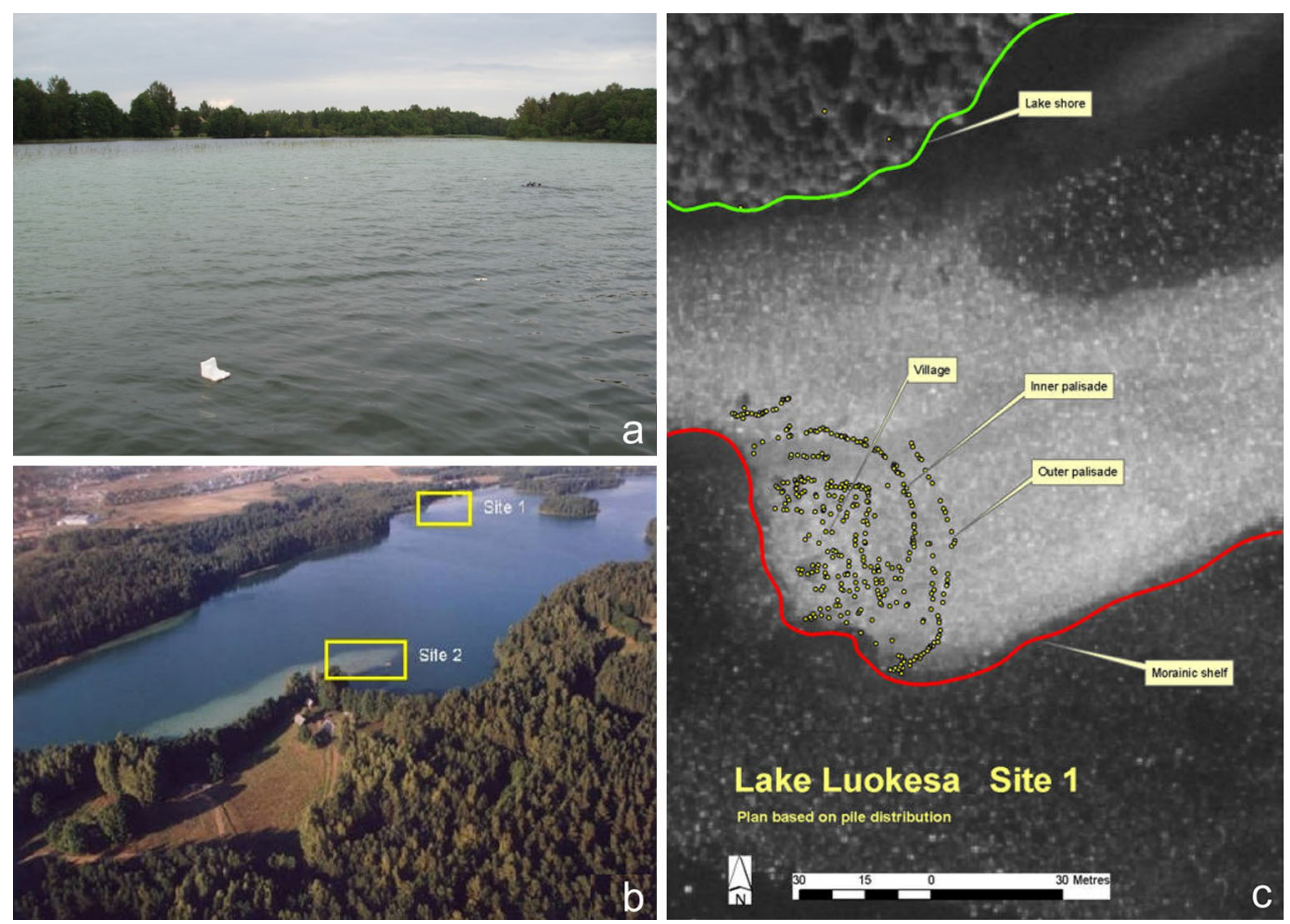

Fig. 1 Location of the site investigated. a Lake Luokesa. b Lake Luokesa with L1 and L2. c The peninsula of L1. Green line lake shore. Red line limit of the shallow area. Little circles piles

recently (Antanaitis-Jacobs and Stančikaitè 2004). Kabailienè focused especially on climate change, and later on the influence of humans on the vegetation. A new summary of results is based on earlier pollen diagrams from 93 different localities (Kabailienè 2006b). A collection of her English publications was published in 2010 as a reprint of her most important works (Kabailiene 2010). Unfortunately, there is very little radiocarbon data in Kabailienè's research, which complicates the chronological correlation between diagrams and hence renders them insufficient from today's perspective. The vegetation and climate history of the Holocene is however found in more recent multidisciplinary studies involving ${ }^{14} \mathrm{C}$ dates (Šinkūnas et al. 2005; Šeirienè et al. 2009).

Archaeologically Lithuania is rich in hillforts. So it was a natural step to also look intensively for prehistoric settlements around lakes. Between 1998 and 2010, 45 lakes and 5 riverbanks were prospected for Neolithic and Bronze Age settlements (Pranckenaite 2011). Although numerous archaeological finds and a few locations with piles were discovered, only two lakes-Lake Liminas on the River Sventoji (Rodiskis District) and Lake Luokesa (Pranckènaite 2010)—produced evidence of lakeshore settlements with piles and other archaeological material. However no pollen diagram for the Liminas site has been published up to now. At the Lake Luokesa, a well-preserved cultural layer with organic material belonging to a lakeshore settlement was excavated and examined for the first time in Lithuania. The palynological study presented here forms part of a wider interdisciplinary project that encompasses archaeological, geo-archaeological and dendrochronological analyses, as well as the examination of botanical macro-remains (Pranckennaite 2014; IsmailMeyer 2014; Bleicher 2014; Pollmann 2014).

Unfortunately very few pollen-analytical studies are connected with archaeological finds or excavations. Most settlements are located on sandy ground, so that no organic material is preserved (Pranckenaite 2011). Thus, the excavation on the edge of a lake at Luokesa (Fig. 1) is of great scientific importance, as pollen-rich sediments could be recovered there. As early as 2007, Motuzaite-Matuzevičiūtè analysed 4 samples from a $29 \mathrm{~cm}$-long core taken from an unspecified location within the settlement area. However, there are as yet no conclusive results, due to the small number of samples taken from this core, from which only a very small amount of pollen has been counted (Motuzaite-Matuzevičiūtė 2007).

The area near Luokesa that has been most thoroughly studied by pollen analysis is located $50 \mathrm{~km}$ east of Moletai, at Lake Kretuonas in the district of Svencionys; this is where more than 30 archaeological sites are known and where the settlement site of Zemaitiske 2, a Late Neolithic pile-dwelling settlement, is located (Fig. 2). The diagram data originate from the vicinity of this settlement, but there are no cultural layers, hardly any settlement indicators and the data are indicative of the Subboreal with dominant 
Pinus (Kabailienė and Grigiene 1997; Girininkas 2008; Antanaitis-Jacobs et al. 2002).

Juodonys is also an off-site diagram. The site is located $60 \mathrm{~km}$ north of Luokesa in an area populated since the Middle Neolithic, but the diagram itself is not directly connected with any specific settlement. It shows the first traces of human impact from approximately 5,900 BP ( $\sim 4800$ cal BC). From the Late Bronze Age (LBA) onwards the presence of fires as well as developing grassland, forest pasture and arable land strongly increases (Stančikaitè et al. 2004).

The lake area in the valley of the Katra lies in southern Lithuania, $180 \mathrm{~km}$ south-west of Luokesa; it contains, amongst others, Lake Duba and Lake Pelesa (Fig. 2). Signs of occupation from the Mesolithic to the Middle Ages have been found there. Two off-site pollen diagrams, taken from lakes that silted up over 100 years ago, show the increasing influence of people from the Late Neolithic onwards (Stančikaitè et al. 2002). It has been shown that deforestation in these areas (Lake Gruda) became more intense in the Bronze Age (Antanaitis-Jacobs and Stančikaite 2004). A multidisciplinary study showed declining water levels in Lake Pelesa during the Subboreal (Šinkūnas et al. 2005). Furthermore, the theory that Alnus declined due to human impact at the beginning of the Early Bronze Age is a debated subject (Saarse et al. 2010).

The remaining wetland settlements that have been investigated archaeologically, and for which pollen diagrams are available, are far from Moletai. These settlements are Sventoji on the Baltic Sea (Stančikaitè et al. 2009b) and Turlojiske near the border with Poland (Antanaitis-Jacobs et al. 2002). Unfortunately, these diagrams do not contain cultural layers. The diagrams from the cultural layer of a dryland settlement from the Impiltis area, in north-western Lithuania, are low in pollen concentration and cover the period from $\mathrm{AD} 900$ onwards (Stančikaite et al. 2009a).

The present study, based on the pollen analysis of the cultural layer of Luokesa, is intended to provide information on the genesis of the cultural layer, on the location of the settlement relative to the shoreline and on the occupation phases. It attempts to reconstruct the vegetation in the immediate and wider environment of the settlement. The sediments below the cultural layer provide information on the vegetation history before the time of occupation of the settlement that corresponds to the cultural layer.

The area of investigation

Lake Luokesa is located on the Baltic Ridge in the Uplands area south of the city of Moletai (Utena County), which lies $63 \mathrm{~km}$ NNE of the capital Vilnius (Fig. 2). Geologically, the area consists of sandstones, clays, dolomites, sands and marl from the Devonian period. The lake is located in the lake region of a moraine landscape that formed during the retreat of the glaciers belonging to the Weichselian Glaciation, and it is connected to other smaller lakes via streams and canals (Motuzaite-Matuzevičiūtè 2007). The lake is $2.4 \mathrm{~km}$ long, $0.8 \mathrm{~km}$ wide and almost $50 \mathrm{~m}$ deep at its deepest point (Menotti et al. 2005). Today, aside from farmland, the area is wooded with Picea, Pinus and Betula. Geobotanically the area belongs to the Aukstaitija District of hardwood-spruce forests, more precisely to the southern sub-district with pine forests including peaty woodlands with Pinus and Betula (Laasimer et al. 1993). Towards the border with Belarus, Pinus woodland with Sphagnum becomes increasingly dominant. The important Central European forest trees Abies, Fagus and Carpinus do not reach as far as Moletai (Czajkowski et al. 2006). The area has many bogs, which have been partly drained. On Lake Luokesa, two settlements were discovered in the year 2000: site L1, located on the northern shore, and site L2 on the southern shore, both being so-called pile-dwellings. L1 can be attributed territorially and chronologically to the Brushed Pottery culture (for details see Pranckènaite 2014).

Pollen analysis was carried out only on L1. In addition to piles, palisades and horizontal wooden structures, L1 possesses an impressive $60 \mathrm{~cm}$-thick cultural layer rich in archaeological material. This cultural layer lies on thick lake marl sediments. Today, L1 lies covered by shallow water (ca. 110-190 cm depth) on top of a moraine-like shoal, which leads from the shore to a small, wooded island (Menotti et al. 2005; Pranckenaite 2014). At the time of its occupation, when the lake level was low, there was presumably a link connecting the settlement to the land, so that it stood on a kind of peninsula. The settlement site covers an area of $50 \times 70 \mathrm{~m}$ and is enclosed on the shoal side by an inner and an outer palisade and is open towards the open water. Only a small part of the settlement has been excavated since 2007, namely 8 squares each $2 \times 2 \mathrm{~m}$, located at the suspected centre of L1 (Pranckènaitè 2014).

L2, now also under water, is located on a shoal and consists of a roughly $190 \mathrm{~m}^{2}$ wooden platform. No cultural layer with finds is available; no pollen analysis was undertaken at this site.

\section{Materials and methods}

Location and retrieval of the core samples

For the archaeobotanical investigation 12 cores from the excavation area itself, and 9 cores collected along 2 transects were retrieved in 2008. The cores were packed in plastic tubes, sealed in foil, transported to Switzerland and stored in a refrigerator. 
Fig. 2 Physical map of Lithuania. Location of the studied site (8) and the other Lithuanian localities cited in the text. 1 Sventoji site. 2 Impiltis hill site. 3 Zadeikiai bog. 4 Birzulis Lake. 5 Baltys Lake. 6 Juodonys settlement. 7 Lake Kretuonas/Zemaitiske site. 8 Lake Luokesa, studied site. 9 Varenis Lake. 10 Lake Duba, Lake Pelesa. 11 Lake Gruda. 12 Turlojiske site. 13 Lake Wigry (Poland)

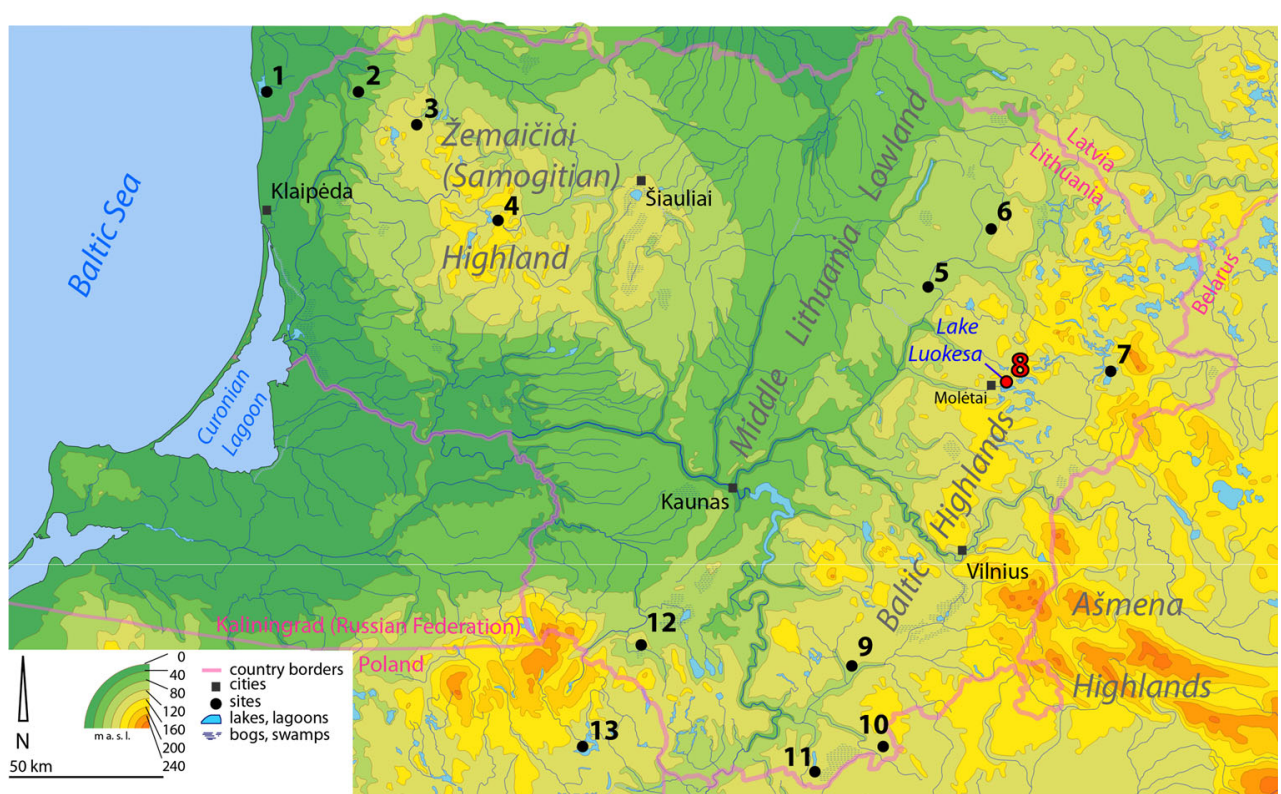

Five cores were selected for pollen-analytical processing. The two profiles LALU15 and LALU13 lie within the palisade in the centre of $\mathrm{L} 1$ and are situated $2 \mathrm{~m}$ apart from each other. LALU4 and LALU2 lie $6 \mathrm{~m}$ away in the direction of the moraine-like shoal. The LALU104 core was taken $22 \mathrm{~m}$ further away, between the inner and outer palisade (Fig. 3).
Pollen analysis

To obtain comparable results from the pollen analysis, macrofossil analysis and micromorphology, the relevant investigations were carried out on the same cores. For pollen analysis material was removed from the cores either every 1 or $2 \mathrm{~cm}$ or at greater intervals; $1 \mathrm{~cm}^{3}$ of material

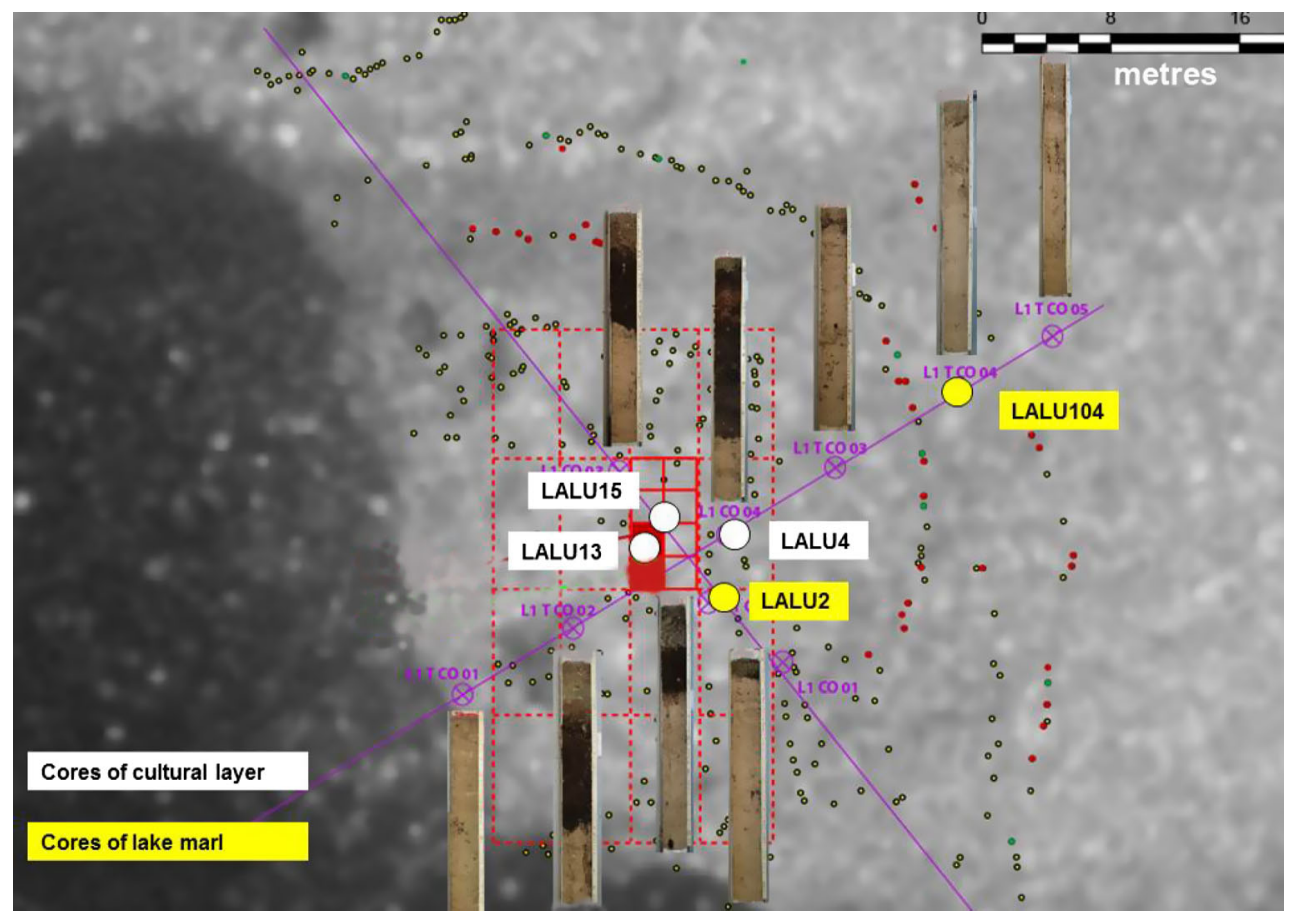

Fig. 3 Location of the sediment cores analysed palynologically at L1; white circles sediment cores with cultural layer. Yellow circles sediment cores with lake marl. Red lines planed fields of excavation.
Red square excavation 2008. Violet lines axes of transects. Little colored circles piles in the settlement and palisades 
was removed at each horizon. Additionally, 4 dung samples were collected from one core (LALU15). A constant number of Lycopodium spores were added to calculate the pollen concentration (Stockmarr 1971). The selected sediment samples were prepared using the standard method in the laboratory of the Institute of Plant Sciences at the University of Bern (Moore et al. 1991). In some samples, in addition to $\mathrm{HCl}$ treatment, $\mathrm{HF}$ was necessary to remove the silicates. After this, acetolysis was carried out. A pollen sum of 800 was sought; although in some of the poorer cultural layers a smaller number had to suffice. The counting was performed using the computer program TAXUS, whilst the calculations and diagram drawings were carried out using the TILIA and TILIAGRAPH programs. The sample numbers correspond to the depth in $\mathrm{cm}$, beginning at the lower end of the tube for easy connection with the altitude above sea level. The upper end of the tube corresponds to the surface at the bottom of the lake. Within the timeline, the diagrams were classified into diagram sections (DS) to allow better comparison of the diagrams with each other. It was decided to select DSs rather than LPAZs (local pollen assemblage zones) because changes in the pollen spectra of cultural layers cannot be equated with changes in local biodiversity. The DSs in turn were assigned to chronozones as defined by Mangerud et al. (1974). DS 4, 5 and 6 comprise the Late Bronze Age / Early Iron Age (Brushed Pottery culture; Pranckenaite 2014).

The percentages refer to the basic sum consisting of pollen and Pteridophyta spores minus pollen of aquatic taxa. The curves shown in the NAP (non-arboreal pollen) part of the diagrams are presented in ecological indicator groups. These groups contain rather different taxa: e.g. the group Lakeside area includes plants of alluvial forests, lakeshore woodlands, wetlands, wet meadows and fen meadows (Alno-Padion, Filipendulion, Molinion). Although a classification based on the main distribution area of a species or plant family was undertaken, the indicator groups are not always reliable representations of the habitat of a plant because the ecological amplitude of the species is often greater than shown. This must be kept in mind when interpreting the information (Behre 1981). Although continuous sedimentation is not expected in cultural layers, it was decided to present the data in curves and not in bars, in order to facilitate comparison with the values obtained for the lake marl. It is only for the 4 dung samples that bar graphs have been used.

\section{Sediment types}

The cores examined contain two types of sediment: light lake marl and dark brown deposits belonging to the socalled cultural layer. The lake marl deposited below water level consists largely of biogenic precipitated chalk and very little organic matter. The cultural layer that had developed consists mainly of organic material, i.e. plant and animal remains, as well as archaeological finds (see below and Ismail-Meyer 2014). Four coprolites from sheep/goats were also recovered from this cultural layer.

The sediment thickness of the layers and the number of horizons (samples) analysed can be found in Fig. 4.

\section{Radiocarbon dating}

A total of 11 AMS datings were made on the LALU2, LALU104 and LALU15 diagrams; they were carried out on charcoal or botanical macro-remains at the AMS- ${ }^{14} \mathrm{C}$ Laboratory of the ETH (Swiss Federal Institute of Technology) Zurich (Table 1). Sample 12 from the LALU101 turned out to be part of a sub-recent rhizome. Unfortunately, the data from the cultural layer lie on a 'plateau' in the ${ }^{14} \mathrm{C}$ calibration curve around $800 \mathrm{cal} \mathrm{BC}$, meaning precise dating of the cultural layer could not be obtained. However, this was improved by comparison with wigglematching of radiocarbon-dated wood samples from dendrochronologically examined piles (Bleicher 2014). This suggests a date for the settlement of between 625 and 535 $\mathrm{BC}$, marking the period in which all wiggle-matching results overlap. This constitutes a reasonable match for our AMS data (see comment on the remaining data in the text). Building activity is attested for at least 15 years at L1; L2 is about 25 years older than L1 (Bleicher 2014).

\section{Results}

Pollen spectra and chronology of the lake sediments below the cultural layer

The lake marl layers below the cultural layer can be arranged into 3 DSs. The lowest (earliest, DS 1) reflects the dominance of Pinus in the younger Atlantic period. DS 2 shows Pinus still dominant but with rising Picea in the Subboreal period. Lastly DS 3 at the top illustrates the time before the beginning of the settlement recorded in the cultural layer and the transition to the Subatlantic period, with high values for Betula.

The pollen spectra of DS 1 (Figs. 5, 6; LALU104 samples 6-42, LALU2 samples 2-6, late Atlantic) are dominated by Pinus whilst Picea is subordinate. As expected, Alnus and Betula, which thrive in the vicinity of shores, have somewhat higher values whilst the rest of the pollen from the other deciduous species shows lower values. Very little grass and other herb pollen is present.

The date of 2,540 вр (700-540 cal вс; LALU2, Table 1) corresponds to the age of the cultural layer and is therefore 
Fig. 4 Lithology, number of samples, thickness of layers and $D S$ diagram sections;

$C$ coprolites; $C h Z$ chronozones; $A P$ archaeological period

\begin{tabular}{|c|c|c|c|c|c|c|c|c|c|}
\hline \multirow[t]{3}{*}{ Lithology } & \multicolumn{6}{|c|}{ Pollen diagram } & \multirow[t]{3}{*}{ DS } & \multirow[t]{3}{*}{$\mathrm{ChZ}$} & \multirow[t]{3}{*}{$\mathrm{AP}$} \\
\hline & \multicolumn{2}{|c|}{ LALU15 } & \multirow[t]{2}{*}{ LALU13 } & \multirow[t]{2}{*}{ LALU4 } & \multirow[t]{2}{*}{ LALU2 } & \multirow[t]{2}{*}{ LALU104 } & & & \\
\hline & & $\mathrm{C}$ & & & & & & & \\
\hline \multirow{3}{*}{$\begin{array}{l}\text { Cultural layer } \\
\text { No of samples }\end{array}$} & 3 & & & & & & 6 & \multirow{4}{*}{ SA } & \\
\hline & 6 & 3 & 6 & 1 & & & 5 & & EIA/LBA \\
\hline & 9 & 1 & 5 & 4 & 1 & & 4 & & \\
\hline \multirow{3}{*}{$\begin{array}{l}\text { Lake marl } \\
\text { No of samples }\end{array}$} & 8 & & 4 & 4 & 2 & 4 & 3 & & \\
\hline & 2 & & 3 & & 8 & 6 & 2 & SB & \\
\hline & & & & & 3 & 7 & 1 & AT & \\
\hline Total samples & 28 & 4 & 18 & 9 & 14 & 17 & & & \\
\hline
\end{tabular}

\begin{tabular}{|l|c|c|c|c|c|c|c|c|}
\hline $\begin{array}{l}\text { Cultural layer } \\
\text { thickness (cm) }\end{array}$ & 60 & 47 & 7 & 5 & & & EIA/LBA \\
\hline $\begin{array}{l}\text { Lake marl } \\
\text { thickness (cm) }\end{array}$ & 17 & 13 & 2 & 50 & 86 & & & \\
\hline
\end{tabular}

Table 1 Radiocarbon dates, Lake Luokesa, site L1

\begin{tabular}{llllrll}
\hline Lab.code & Core & Depth & Material & Weight $(\mathrm{mg})$ & ${ }^{14}$ C-age (years BP) & Cal. age (BC) \\
\hline ETH-42977 & LALU2 & $4 \mathrm{~cm}$ & Charcoal (2 pieces) & 7.0 & $2,540 \pm 35$ & $700-540(58.3 \%)$ \\
ETH-42978 & LALU2 & $13 \mathrm{~cm}$ & Bark & 18.2 & $4,855 \pm 35$ & $3710-3630(79.2 \%)$ \\
ETH-42979 & LALU2 & $29 \mathrm{~cm}$ & Bark (2 pieces) & 9.9 & $2,520 \pm 35$ & $800-520(95.4 \%)$ \\
ETH-42980 & LALU2 & $51 \mathrm{~cm}$ & Hazelnut, shell (1 piece) & 113.0 & $2,515 \pm 35$ & $800-520(95.4 \%)$ \\
ETH-42981 & LALU15 & $22 \mathrm{~cm}$ & Charred bark (2 pieces) & 14.5 & $2,500 \pm 35$ & $790-500(94.2 \%)$ \\
ETH-42982 & LALU15 & $25 \mathrm{~cm}$ & Charred bark (2 pieces) & 19.2 & $2,565 \pm 35$ & $810-740(56.7 \%)$ \\
ETH-42983 & LALU15 & $34 \mathrm{~cm}$ & Charred branch (1 piece) & 283.4 & $2,530 \pm 35$ & $800-530(95.4 \%)$ \\
ETH-42984 & LALU104 & $40 \mathrm{~cm}$ & Bark (1 piece) & 24.9 & $5,255 \pm 40$ & $4180-3970(82.5 \%)$ \\
ETH-42985 & LALU104 & $62 \mathrm{~cm}$ & Branch (1 piece) & 9.9 & $4,785 \pm 35$ & $3650-3510(93.7 \%)$ \\
ETH-42986 & LALU104 & $79 \mathrm{~cm}$ & Branch (1 piece) & $<290.7$ & $2,530 \pm 35$ & $800-530(95.4 \%)$ \\
ETH-42987 & LALU104 & $85 \mathrm{~cm}$ & Charcoal (1 piece) & 30.7 & $2,520 \pm 35$ & $800-520(95.4 \%)$ \\
ETH-42988 & LALU101 & No pollen & Rhizome (1 piece) & 68.2 & $150 \pm 35$ & AD 1660-1960 $(95.4 \%)$ \\
\hline
\end{tabular}

too recent. As such it must be interpreted as material derived from the cultural layer which was most probably pushed down to this depth because of a pile hole; indeed the piles partly reach as far as $4.5 \mathrm{~m}$ below the cultural layer (Menotti et al. 2005). The date of 5,255 вр (4180-3970 cal BC; LALU104, $44 \mathrm{~cm}$ below the cultural layer) can be considered correct and indicates the Late Atlantic period. The rise of Alnus at the beginning of the Atlantic, as shown in some Lithuanian diagrams (Antanaitis-Jacobs et al. 2002; Stančikaite et al. 2002), is not visible in the diagrams of Luokesa. LALU104 reaches further back than LALU2, but ultimately does not reach an older pollen zone. Furthermore, this data-set shows that the decline of deciduous trees such as Ulmus, Tilia and Corylus has already taken place (Šinkūnas et al. 2005) or alternatively that the mixed oak forest (Quercetum mixtum, QM) never had such high values as in the diagram for Balthys Lake (Š́eirienè et al. 2009).
In the pollen spectra of DS 2 (Figs. 5, 6, 8, 9; LALU104 samples 48-78, LALU2 samples 12-48, LALU13 samples 2-6 and LALU15 samples 2-8, Subboreal) Pinus is dominant. Picea shows a peak in both lake marl diagrams (LALU104, LALU2) at the bottom of this diagram section. Picea then recedes and slowly rises again in the upper part of DS 2. Alnus and Salix also have partly slightly higher values. The lowest horizons of the diagrams LALU13 and LALU15 match. Sample 8 in LALU15 is very low in pollen and, in addition to high values for Alnus, Betula and Tilia, has extremely low Pinus and Picea values. The change from the Atlantic to the Subboreal period is otherwise hardly noticeable, which is also indicated in other diagrams such as those of Lake Varenis in south-eastern Lithuania (Šeiriene et al. 2009). According to the general vegetation history of Lithuania there was, at the transition of the Atlantic to the Subboreal, a decline of the QM (Kabailiene 1998, 2006a, 
2010) which is not as pronounced here-this is consistent with adjacent diagrams (Girininkas 2008).

The dates 4,855 вр (3710-3630 cal вс; LALU2) and 4,785 вр (3650-3510 cal вс; LALU104) (Table 1) lie in the early Subboreal. The Picea-increase (LALU2 sample 48, LALU104 sample 72) at the end of the Subboreal possibly corresponds to the documented Picea-increase around 3,100 BP (ca. 1350 cal BC) in north-western Lithuania (Zadeikiai and Birzulis Lakes) when Picea became a
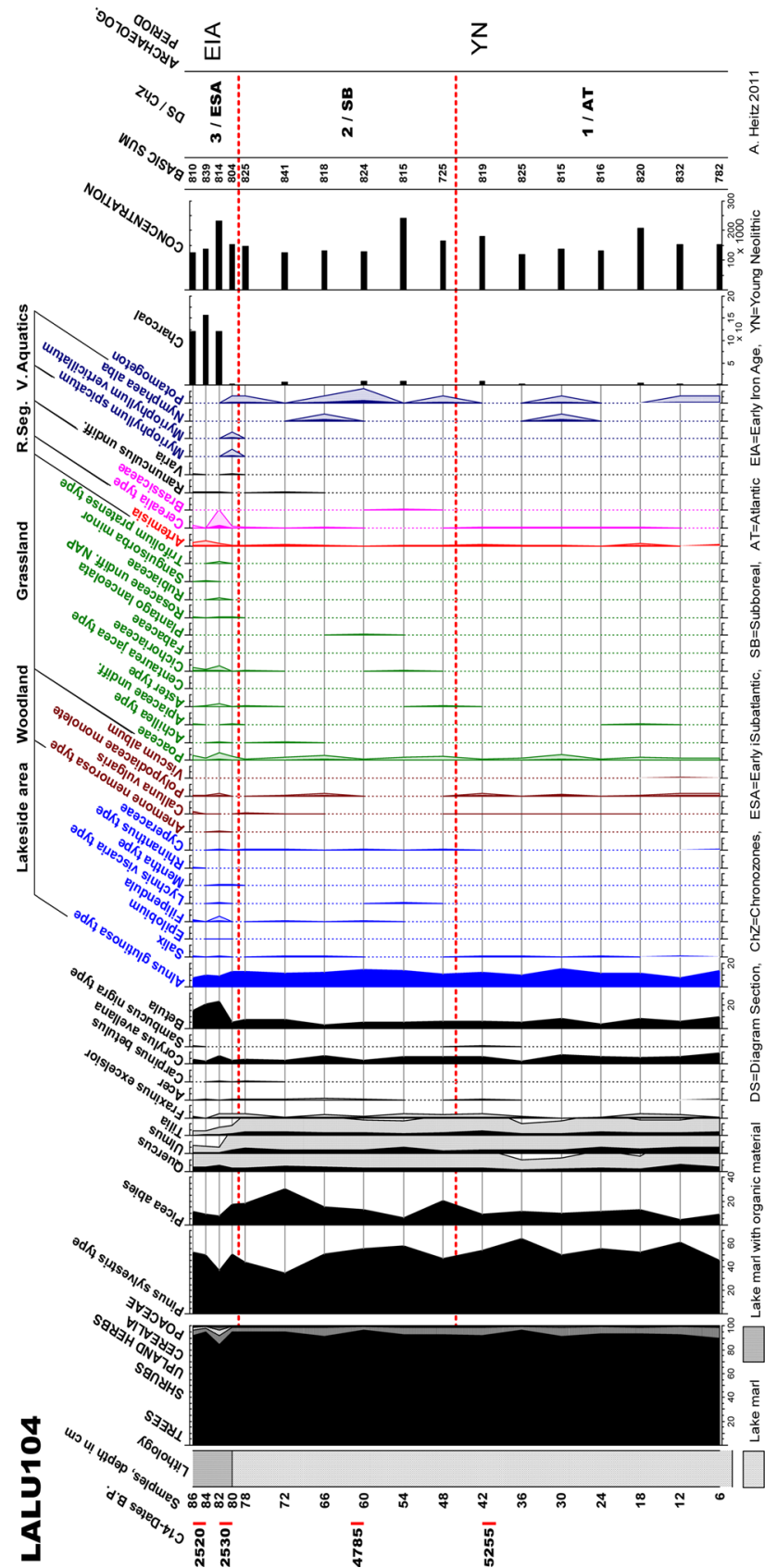

Fig. 5 Pollen diagram, Lake Luokesa 104 leading member of the forest composition (Stančikaite et al. 2003, 2006). According to Kabailiene (2006a) also, the course that the Picea curve follows corresponds to the

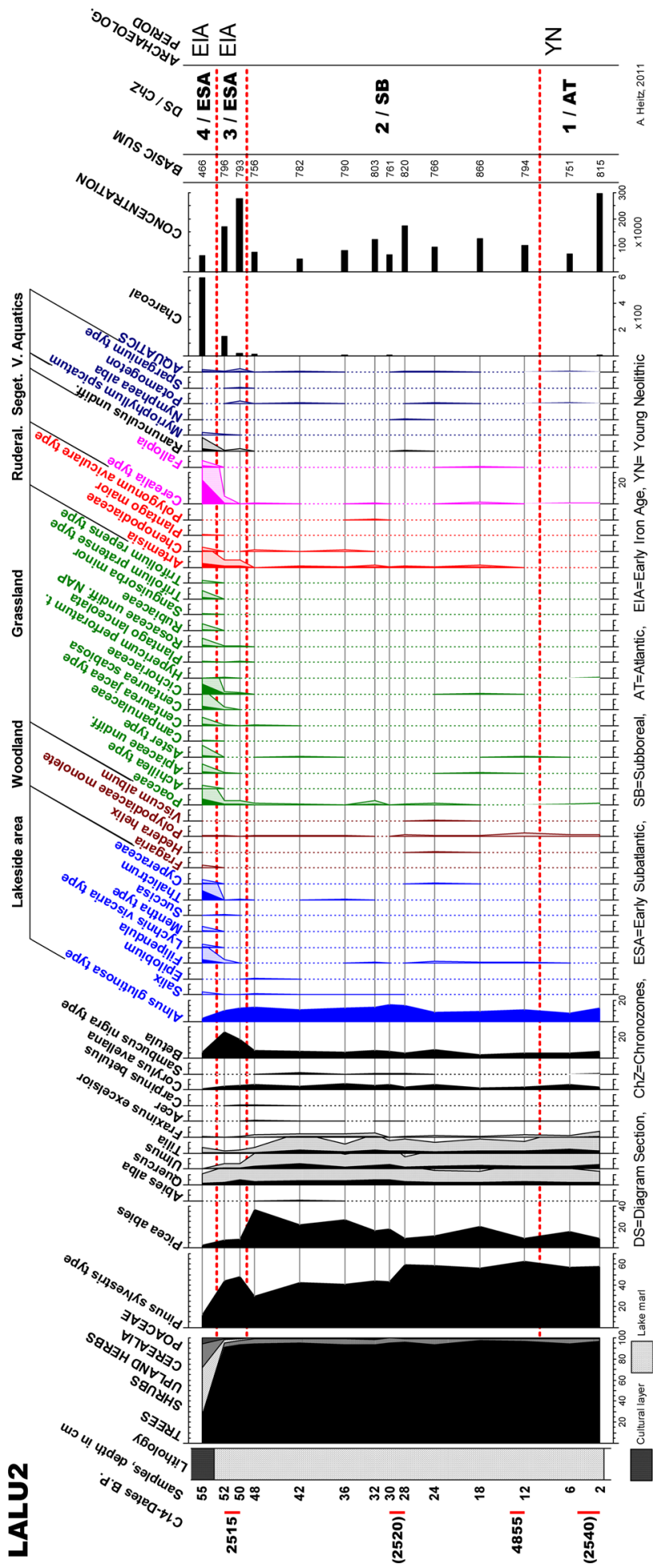

Fig. 6 Pollen diagram, Lake Luokesa 2 


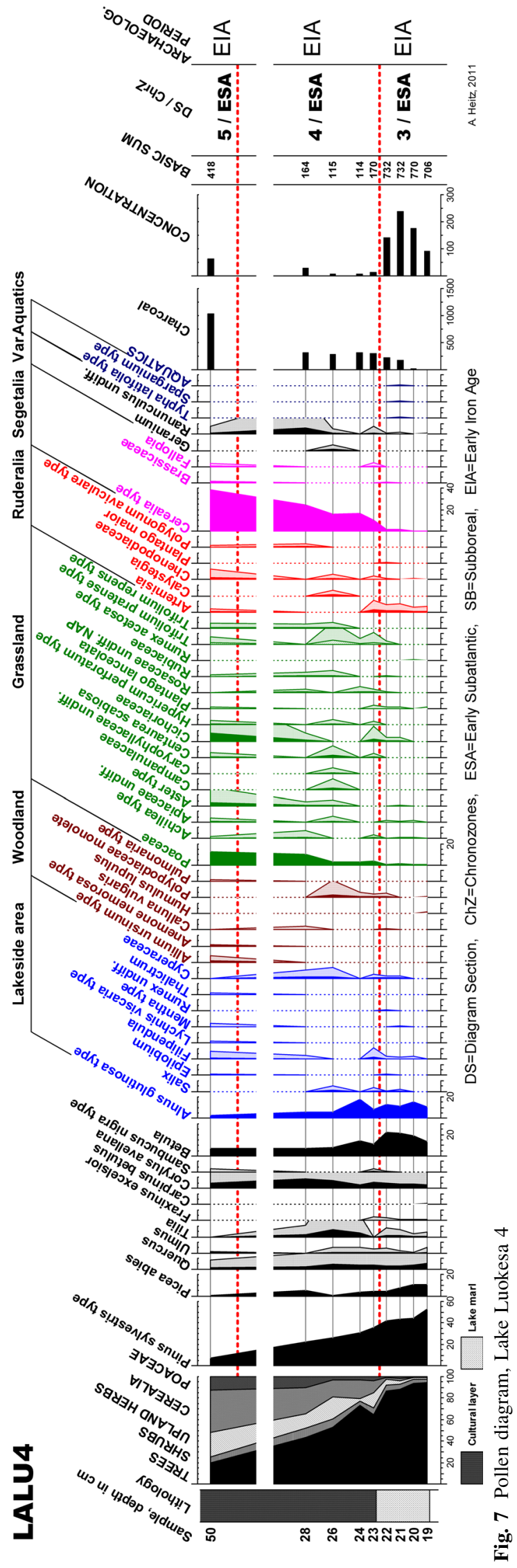

Subboreal period. The date of 2,520 BP (LALU2 $800-520$ cal BC), however, is too recent and needs to be discarded (see above). Typically, both data-sets that are too recent (DS 1, DS 2) come from the LALU2 core, which lies near the centre of L1 and which contains material from the cultural layer in the upper part of the sample. On the other hand, LALU104, which lies between the inner and outer palisades and has no cultural layer, resulted in no erroneous data. In the latter case, a downward spread of material derived from the cultural layer is also unlikely. From a pollen-analytical perspective this spread of material is not detectable in the diagram.

In all five diagrams, DS 3 (Figs. 5, 6, 7, 8, 9; LALU104 sample 80-86, LALU2 sample 50-52, LALU4 sample 19-22, LALU13 sample 8-13, LALU15 sample 10-17, early Subatlantic) shows a decline of Picea while a significant increase of Betula is recognisable; three diagrams also show a weak increase of Alnus. Moreover, an increase in pollen concentration to high values is noticeable. The herb pollen spectrum still has small values and is poor in species. Only Cyperaceae, Filipendula, Cichoriaceae and Artemisia have slightly higher values. From here on however, Carpinus regularly appears with fewer pollen grains. The curves of AP (arboreal pollen) oscillate a little more than in DS 2. The transition to the Subatlantic period in the pollen spectrum is only slightly noticeable-which is consistent with other diagrams (Stančikaite et al. 2002, 2004). However, in north-western Europe a significant change from warm and dry to cool and moist can be seen (van Geel and Magny 2002).

The dates of 2,515, 2,530 and 2,520 вр (800-520 cal вс; Table 1) roughly show the age of the cultural layer. 2,515 and 2,530 BP lie in the lake marl just below the cultural layer. They indicate the minimum age of the beginning of the settlement. They also indicate the beginning of the Subatlantic, which therefore starts with an increase in the Betula curve. It would also be possible to set the limit at the sharp rise of the NAP values directly at the bottom of the cultural layer, but since this change in the pollen curve is of anthropogenic origin, it is not relevant for the setting of the boundary.

Pollen spectra at the transition from the lake marl to the cultural layer

In the five cores investigated the transition from the lake marl to the cultural layer was about $4-8 \mathrm{~cm}$ thick. It was analysed at $1 \mathrm{~cm}$ (LALU4, LALU13, LALU15) or $2 \mathrm{~cm}$ intervals (LALU 2, LALU104) and compared with the cultural and lake marl layers above and below. The results, as well as their possible interpretation, are recorded in Table 2. 


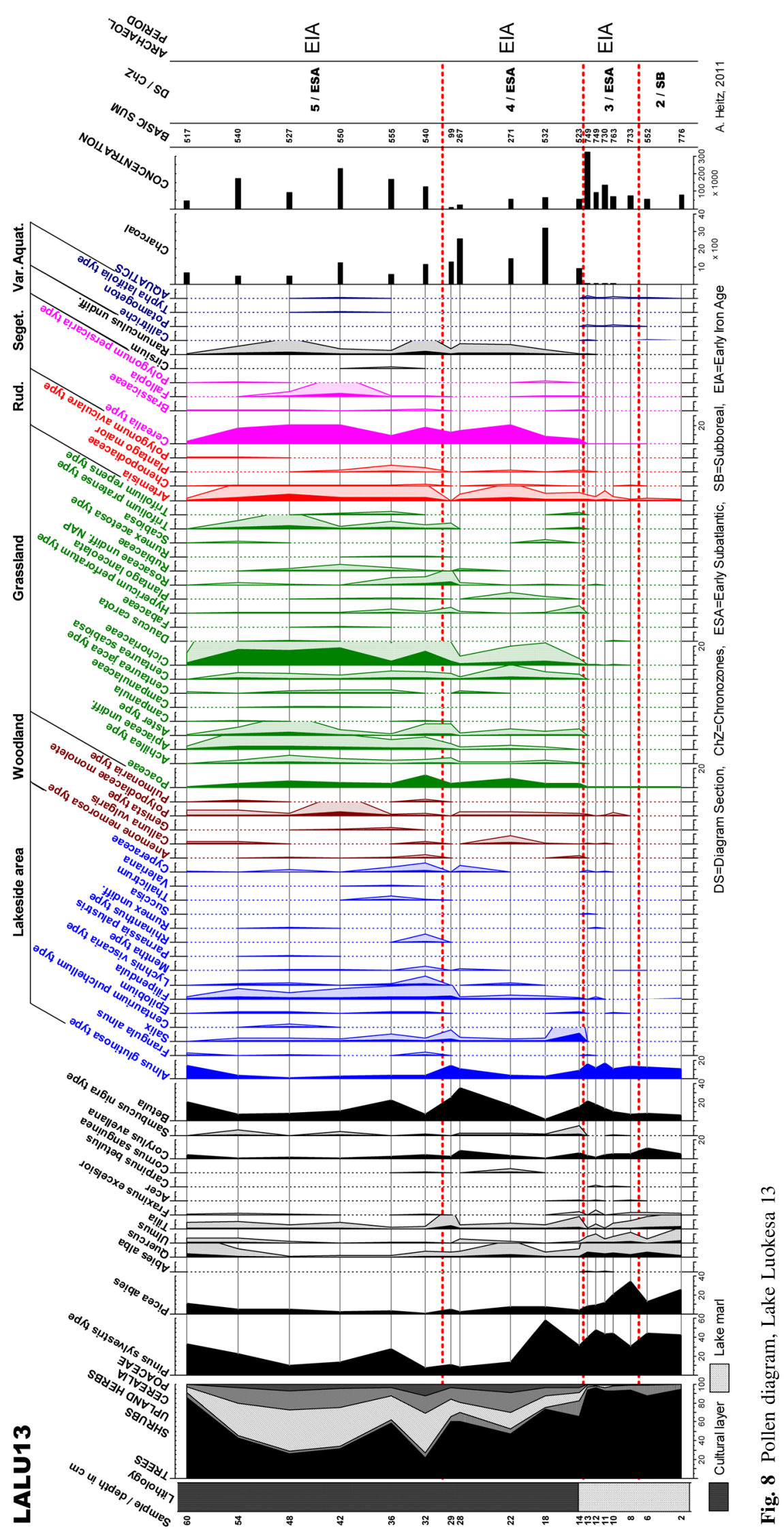




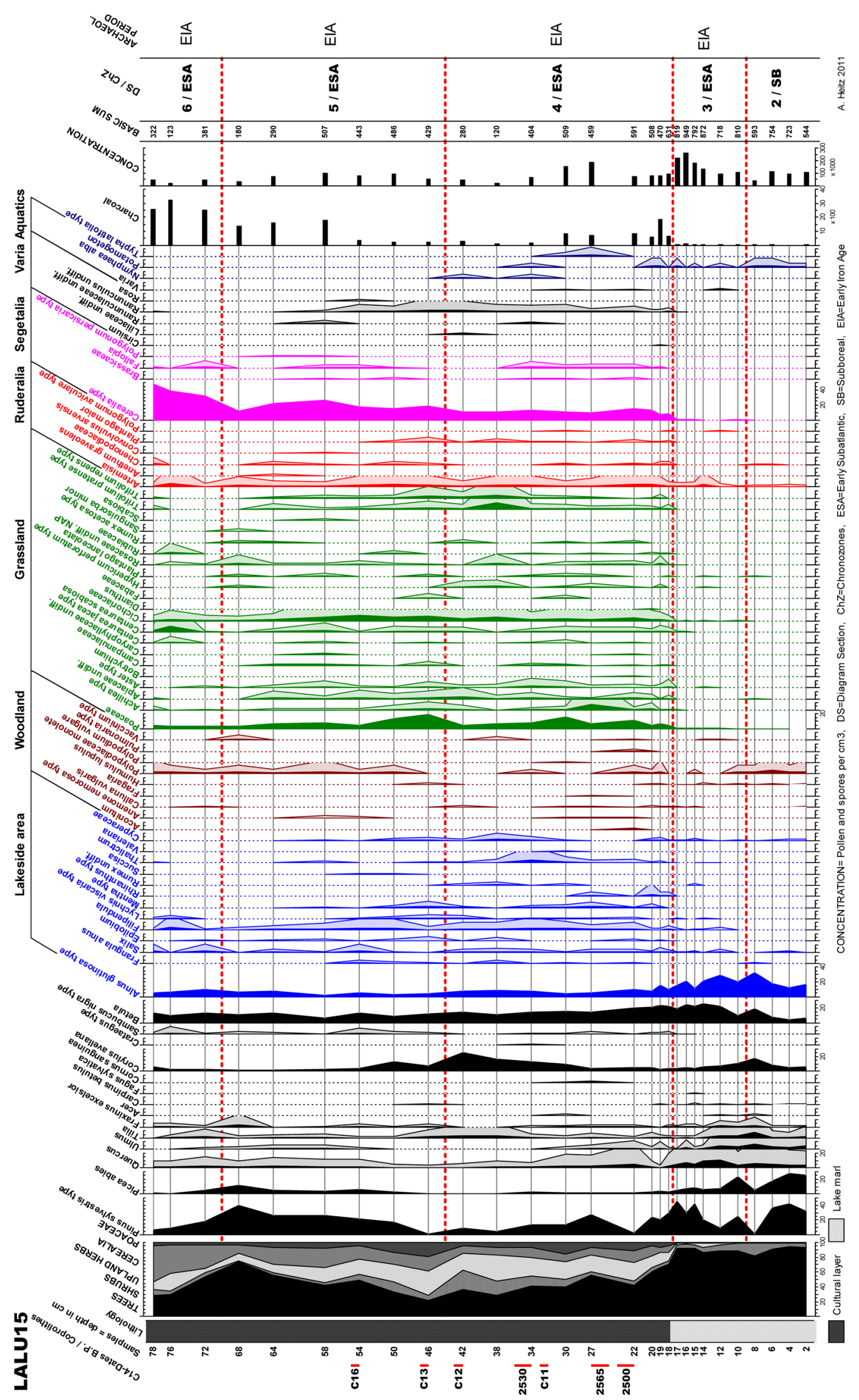

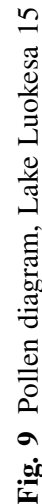


Table 2 Results of $1 \mathrm{~cm}-/ 2 \mathrm{~cm}$-pollen analysis at the transition of lake marl to cultural layer

\begin{tabular}{|c|c|c|c|c|}
\hline \multirow{2}{*}{$\begin{array}{l}\text { Diagram } \\
\text { (samples } \\
\text { of } \\
\text { transition) }\end{array}$} & \multirow[t]{2}{*}{ Hiatuses } & \multicolumn{2}{|l|}{ Local vegetation on the lakeshore } & \multirow[t]{2}{*}{ Human impact } \\
\hline & & Aquatic plants & Lakeside area & \\
\hline $\begin{array}{l}\text { LALU15 } \\
(14-20)\end{array}$ & $\begin{array}{l}\text { At the bottom of the cultural } \\
\text { layer the pollen curves change } \\
\text { abruptly (18) and a peak of } \\
\text { Pinus (17) is noticed: no } \\
\text { continuous sedimentation is } \\
\text { supposed }\end{array}$ & $\begin{array}{l}\text { Aquatic plants are } \\
\text { documented but not } \\
\text { frequent at the transition, as } \\
\text { in the lower part of the } \\
\text { cultural layer and lake marl } \\
\text { below }\end{array}$ & $\begin{array}{l}\text { Reeds and lake shore } \\
\text { forests are hardly } \\
\text { recognized at the } \\
\text { transition, Betula values } \\
\text { are noteworthy }\end{array}$ & $\begin{array}{l}\text { Only in the cultural layer L1 } \\
\text { human impact is clearly } \\
\text { recognizable, fluctuating } \\
\text { curves -forest clearance? } \\
\text { Some percentage of Artemisia. } \\
\text { Betula (in wet forest or fallow } \\
\text { land?) values are noteworthy }\end{array}$ \\
\hline $\begin{array}{l}\text { LALU13 } \\
(10-14)\end{array}$ & $\begin{array}{l}\text { A peak of Pinus (12) and high } \\
\text { pollen frequency (13) could } \\
\text { indicate a hiatus }\end{array}$ & $\begin{array}{l}\text { Aquatic plants are rare, but } \\
\text { recognizable in the lake } \\
\text { marl layers }(10-13) \text { at the } \\
\text { transition }\end{array}$ & $\begin{array}{l}\text { Riparian woodland with } \\
\text { Salix (14) is clearly } \\
\text { recognizable at transition, } \\
\text { Cyperaceae almost } \\
\text { absent, Betula }(13) \text { is } \\
\text { present }\end{array}$ & $\begin{array}{l}\text { A significant change in the } \\
\text { sediment and diagram: } \\
\text { beginning of the culture- } \\
\text { indicating pollen. Betula (13) } \\
\text { is present }\end{array}$ \\
\hline $\begin{array}{l}\text { LALU4 } \\
(19-24)\end{array}$ & $\begin{array}{l}\text { Change of pollen frequency and } \\
\text { bad preservation (23) indicate } \\
\text { a hiatus and dry conditions }\end{array}$ & $\begin{array}{l}\text { Aquatic plants are almost } \\
\text { absent, only a few at the } \\
\text { transition (21) }\end{array}$ & $\begin{array}{l}\text { Reeds and Filipendula are } \\
\text { just recognizable at the } \\
\text { top of lake marl layers } \\
(21-23), \text { Betula with high } \\
\text { values }\end{array}$ & $\begin{array}{l}\text { Human impact starts with the } \\
\text { sedimentation of charcoal and } \\
\text { upland herbs immediately } \\
\text { before the settlement, Betula } \\
\text { with high values }\end{array}$ \\
\hline $\begin{array}{l}\text { LALU2 } \\
(48-55)\end{array}$ & $\begin{array}{l}\text { A significant change in the } \\
\text { diagram }(52 / 55) \text { indicates no } \\
\text { continuous sedimentation }\end{array}$ & $\begin{array}{l}\text { Some aquatic plants are } \\
\text { shown at the bottom of the } \\
\text { cultural layer and the lake } \\
\text { marl layer at the transition } \\
(50,55)\end{array}$ & $\begin{array}{l}\text { Wet meadows and lake } \\
\text { shore forests are weakly } \\
\text { recognizable at the } \\
\text { transition }(52,55), \text { Betula } \\
\text { peak }(52)\end{array}$ & $\begin{array}{l}\text { Increase of culture-indicating } \\
\text { pollen at the bottom of the } \\
\text { cultural layer, almost absent in } \\
\text { lake marl. Betula peak ( } 52)\end{array}$ \\
\hline $\begin{array}{l}\text { LALU104 } \\
(78-86)\end{array}$ & $\begin{array}{l}\text { The cultural layer is missing in } \\
\text { the core, no interpretation }\end{array}$ & $\begin{array}{l}\text { Aquatic plants are found in } \\
\text { the lake marl below the } \\
\text { cultural layer }(78,80)\end{array}$ & $\begin{array}{l}\text { Reeds and wet meadows } \\
\text { are almost absent at the } \\
\text { transition, Betula } \\
\text { increasing }\end{array}$ & $\begin{array}{l}\text { Culture-indicating pollen and } \\
\text { charcoal almost absent. Betula } \\
\text { increasing }\end{array}$ \\
\hline Conclusion & $\begin{array}{l}4 \text { diagrams show probable } \\
\text { drying and a small hiatus } \\
\text { before the settlement L1 } \\
\text { (LALU104: missing sediment) }\end{array}$ & $\begin{array}{l}\text { Aquatic plants are } \\
\text { underrepresented. They are } \\
\text { documented in the lake } \\
\text { marl and the lower part of } \\
\text { the cultural layer }\end{array}$ & $\begin{array}{l}\text { No big reeds are } \\
\text { documented on the edge } \\
\text { of the lake in all } \\
\text { diagrams. } \\
\text { Betula has high values just } \\
\text { before the cultural layer, } \\
\text { also Alnus in } 3 \text { diagrams }\end{array}$ & $\begin{array}{l}\text { There are some indications of } \\
\text { forest clearance just before the } \\
\text { settlement L1. High values of } \\
\text { Cerealia and NAP of grassland } \\
\text { in the cultural layer show } \\
\text { intense human impact. Betula } \\
\text { on fallow land? }\end{array}$ \\
\hline
\end{tabular}

Pollen spectra and chronology of the cultural layer

The cultural layer, which belongs to the early Subatlantic, has consistently high NAP values. They can be divided into three DSs. In DS 4 the Pinus values decrease. On the boundary with DS 5 there is a peak in Corylus, Betula and Alnus, with poor pollen concentration. In DS 5 the Pinus values rise again and high records of Cerealia are present reaching maximum values in DS 6.

DS 4 (Figs. 6, 7, 8, 9; LALU2 sample 55, LALU4 sample 23-28, LALU13 sample 14-29, LALU15 sample 18-42, early Subatlantic) is characterised by the change of the sediment from lake marl layer to cultural layer where the proportion of charcoal and NAP increases strongly whilst that of the AP decreases significantly. All tree species, but especially Pinus, decrease. The NAP of all indicator groups increase. The number of taxa, as well as the frequency of NAP, is much higher in LALU15 than in LALU13. This is caused by the LALU15 sediment containing more organic material with pollen introduced by the settlement activities. At the top of DS 4 there is a small Corylus peak, and in LALU13 peaks in Betula and Alnus are also observable.

The dates of 2,500 (790-500 cal BC), 2,565 (810-740 cal BC) and 2,530 BP (800-530 cal BC) in the diagram LALU15 identify the older part of the cultural layer as belonging to the Early Iron Age (EIA). Due to the 'plateau' in the ${ }^{14} \mathrm{C}$ calibration curve at this time, a more precise radiocarbon dating is not possible.

In DS 5 (Figs. 7, 8, 9; LALU4 sample 50, LALU13 sample 32-60, LALU15 sample 46-68, early Subatlantic) the values for wild grasses recede slightly, although on the other hand the species diversity of the grassland plants does not decrease. The Cerealia and their companions increase 
somewhat. Picea has very small values whilst Pinus increases somewhat towards the upper part of the sample. Artemisia also has higher values. Compared to LALU15, LALU13 has higher NAP values, but fewer different taxa. Since the conditions for preservation are worse there than those of LALU15, which is evidenced by the high values of Cichoriaceae, the determination of the genus or species was not always possible; this in turn may have slightly reduced the range of species. The uppermost horizon in LALU13 and LALU15 has low NAP values with poor pollen concentration.

DS 6 (Fig. 9; the uppermost zone of the sediment, LALU15 sample 72-78, early Subatlantic) is recorded in LALU15 only. The AP, in particular that of Pinus, decreases whilst Cerealia, Artemisia, Centaurea and Filipendula increase. The sediment is sandy-clayey. Pollen concentration is low and the proportion of charcoal is particularly high.

\section{Dung samples}

The four dung samples (coprolites of sheep/goat, LALU15Cop Cop11, Cop12, Cop13, Cop 16. Fig. 10) are situated in DS 4 and DS 5 of the LALU 15 diagram. All have in common the fact that they contain only few taxa, little AP, especially little Pinus, almost no cereal pollen and finally no aquatics. On the other hand, in the 4 samples, different pollen types have strikingly high values. These are Poaceae and Betula in Cop11; Varia, Alnus and Betula in Cop12; Apiaceae and Cichoriaceae in Cop13; Epilobium and Fabaceae in Cop16.

\section{Discussion}

Sedimentation of the lake marl and cultural layer and formation of the pollen spectra

The accumulation of lake marl generally takes place at variable water depth. During the period of formation of the lake marl in the Atlantic period and the early Subboreal, the area where L1 was situated lay some $5 \mathrm{~m}$ under water, which corresponds to the current natural depth of water of the shallows located between the mainland and the island (lake-bed mapping by E. Pranckenaitè). The largest part of the sediment that formed at that time consists of carbonates which were precipitated through various living organisms out of the calcareous water. Small quantities of plant and animal remains were also embedded annually, as were sands and clays washed in by rivers. This is how the lake marl sediment, characterised by a fine yellowish-white carbonate mud with little sand and clay (Ismail-Meyer 2014), formed under the cultural layer of L1. This sediment received an annual air-borne pollen rain, which fell on the surface of the lake and then settled, to be embedded in the deposit. The lake marl sediments of $\mathrm{L} 1$ are extremely rich in pollen, as is also the case of many lakes of the circumalpine region. Moreover, the pollen is generally very well preserved, as it reached an anaerobic environment immediately and permanently, and became slowly fossilised. The pollen spectrum consists largely of anemophilous (wind-dispersed) types and it represents mainly the regional vegetation; pollen grains that reached the lake via rivers are quantitatively rare. Different conditions applied to the shallower shore zone, with aquatic plants found more commonly. However, the preservation of their pollen is poor, as their exines contain little sproropollenin (Burga and Perret 1998). Pollen which floats well on the surface of lakes, such as the vesiculate pollen grains of Pinus and Picea can accumulate in the drift line of the lakes and produce a yellow seam. A peak in the pollen spectrum, for example of Pinus, can form in this way, and is indicative of sedimentation in a shore environment (Ammann et al. 1981; Haas and Hadorn 1998); this has also been observed in the Luokesa diagrams.

The so-called cultural layers of the lakeshore settlements are deposited in part in shallow waters and in part also on land above the lake level. They consist of the sediments that produce archaeological assemblages that can generally be attributed to a single cultural phase or period. If upright posts or piles are present, as at L1, then they are dubbed pile-dwellings. It must be established for each individual site whether the settlement was built on a platform above the water or whether it was established on the ground. This forms part of the investigations presented in this publication, and of the contributions from other disciplines (see Pranckénaite 2104; Ismail-Meyer 2014; Pollmann 2014; Bleicher 2014). The cultural layer sediment consists predominantly of organic material. At L1, the proportion of plant remains represents over $50 \%$ of the material throughout: in most cases it is composed of fragments of wood and bark, but twigs, leaves, fruits, seeds, charcoal and mosses are also present. Clay, sand and gravel are also documented (Pollmann 2014; Ismail-Meyer 2014). Much of this material was intentionally brought to the site as consumables, building and insulation material, produce from harvests and gathering, and bedding for livestock; much also reached the settlement accidentally. A large volume was deposited as refuse, and was preserved in the damp environment. Quite different amounts of material can thus accumulate in a given time span, and material deposited during the summer can be distinguished from that accumulated in winter. The materials brought in all come from the shore area and the hinterland of the settlement, i.e. from the zone accessible from it. Layers consisting of coprolites were also recorded, identified on the 
basis of their shape as from sheep/goats and cattle. Dung from sheep is generally indistinguishable from that of goats (Haas 2004). Hence the genesis of cultural layers is complex as is the formation of their pollen spectra as well, but entirely different from that in the accumulation of the lake marl. The pollen of anemophilous plants is naturally windblown, possibly also carried by water, and settled in the cultural layers. In addition, there are other sources of pollen: cereals were brought onto the settlement for threshing, livestock passed through or was stabled on site, people moved around, fruits were processed, pollarded branches were brought in, and tender leaves were used as food. Pollen grains can adhere to all these materials. Once in the layer, the pollen grains are preserved differentially, depending on their immediate environment. If permanently damp, preservation is good, if variably humid, the pollen grains do not always survive. Pollen spectra develop in this way, partly containing, in addition to the normal pollen rain, vast amounts of pollen from most diverse origins. They can also include insect-borne pollen or self-pollinating varieties, which can enter the deposits in large quantities (Heitz-Weniger 1978; Ammann and Liese-Kleiber 1980; Richard 1993; Hadorn 1994). Since the pollen spectra of cultural layers were formed by both the natural sedimentation of pollen grains and by human action that brought materials in, it follows that the spectra do not just mirror the development of the vegetation and hence must be interpreted differently. The pollen that was incorporated into the cultural layers by being imported by people is indicative of their area of origin and it documents the places visited by the settlers. When interpreting the AP curves of a cultural layer, we must take into account that they-like all other curves-are being brought down by extremely high values for other taxa, often of Cerealia.

The main features of the pollen diagrams from the cultural and lake marl layers of L1 do match. The two cultural layer diagrams LALU15 and LALU13 in particular show good parallels, which is easily recognisable in the Total Diagrams (Figs. 8, 9, left). In these cultural layers not only the mosaic-like accumulation of pollen taxa is visible, but also a certain degree of concordance in the horizontal plane. This aspect will also need to be taken into consideration.

The development of the vegetation prior to the accumulation of the cultural layer

During the Late Atlantic (DS 1) vast Pinus forests with some Picea dominated the Luokesa region. Even today, Pinus is the most common forest tree found in the area (Roering 1999). QM elements such as Quercus, Ulmus and Tilia and on rare occasions even Fraxinus were present, but remained subordinate. Despite the fact that the Atlantic period is characterised as a QM-Corylus-Alnus zone by
Kabailiene (2006a), some of the more recent investigations are in accordance with the findings from Luokesa's lower $\mathrm{QM}$ values. Examples of this are the diagram from Juodonys, a radiocarbon-dated site located $60 \mathrm{~km}$ from Luokesa on the edge of the Baltija Upland (Stančikaite et al. 2004), or the diagrams located further away at Lake Duba and Lake Pelesa (Stančikaite et al. 2002) and at Lake Wigry in Poland (Kupryjanowicz 2007). In wetter areas, Alnus was frequent. The Poaceae exhibit very low values, and Cerealia, Artemisia and other NAP are recorded only as isolated grains. Low Artemisia values suggest that these plants cannot be interpreted as indicative of clearances, since they occur in Pinus sylvestris forests. The NAP values indicate that there was a degree of human impact, but that it was still noticeable. The earliest signs of vegetation cover transformation, in the form of human-induced vegetation disturbances, also appear from the early Middle Neolithic onwards as weak signals from the edge of the Baltic Uplands (Stančikaite et al. 2004).

In the Subboreal (DS 2) coniferous forests continue to dominate. A shift towards Picea forest is recorded. The QM remains unchanged and continues to play a subordinate role. The Fraxinus-Alnus forest becomes somewhat more noticeable, having presumably spread along the lake shore. The slight increase in clearance indicators suggests an increased human impact. In the very detailed widely dispersed diagrams LALU13 and LALU15 this phase ends with a horizon that is poor in pollen, suggesting a change in the conditions for sedimentation.

The growing and very high pollen concentrations observable in DS 3 (Subatlantic) of all the diagrams indicates a low rate of sedimentation. It implies pollen enrichment in the shore zone, evidenced by high Pinus values. It is therefore possible to conclude that the level of the lake dropped and that the lake shore expanded. The slightly higher values for Alnus and Filipendula shown in three of the diagrams suggest that shoreline woodland and humid zones increased too. The diagrams from Turlojiske and Zemaitiske (Antanaitis-Jacobs et al. 2002) also indicate that a drop in lake levels is accompanied by an expansion of Alnus woodland. In terms of chronology, these local events need not necessarily to coincide. Other types of wetland areas may also have benefited. In any case, the pollen spectra suggest a freeing up of the shoreline that was then colonised by wetland plants. Betula too shows a marked growth. It is conceivable that this pioneer species expanded in newly cleared zones. However, apart from a little cereal pollen, the evidence for clearance is very weak for the sequence below the cultural layer on the diagram. It is therefore unlikely that major clearances took place before the beginning of the settlement episode. Possiblyand more probably-Betula just benefited from the expansion of the shoreline. 
Pollen from aquatic plants, which would allow conclusions to be drawn about a limnic depositional milieu, is rare and underrepresented. This pollen is especially rare in sediments deposited in deep water (Heitz-Weniger 1978), even though today Potamion (Potamogetonion) can occur at depths of $4 \mathrm{~m}$ and even up to a depth of $7 \mathrm{~m}$. In the Luokesa diagrams the aquatic plants are most common at the transition from the lake marl to the cultural layer and indicate the presence of shallow water. Pollen of Carpinus is present at Luokesa, as it is at Kretuonas (AntanaitisJacobs et al. 2002), in small amounts from the Subboreal onwards. It is likely that this pollen was transported over long distances, given that today the distribution zone of Carpinus is located at a distance of well over $100 \mathrm{~km}$. In southern Lithuania the immigration of Carpinus is proven already since the end of Atlantic (Šinkūnas et al. 2005).

The development of the vegetation at the time of the accumulation of the cultural layer (settlement L1) in the early Subatlantic period

During DS 4 Pinus forests with some Picea were common, even at the time when the cultural layer was being accumulated. Betula stands were now more extensive, possibly having spread on fallow and cleared land. Species from all indicator groups are equally represented in the samples and point to the existence of wetlands, lakeshore sites, wet meadows, grasslands, arable fields and ruderal sites. Settlers and their livestock moved around all these places right from the beginning of the settlement phase. The low pollen concentrations in LALU13 are due to the high proportion of charcoal, which affects the number of taxa identified. As the structures from the settlement are not well known, it remains an open question whether this configuration represents the presence of hearths in the settlement. There are no indications of an extended sedge belt.

In DS 5 the surrounding woodlands are still dominated by Pinus, with some Picea present. In LALU15, conifer pollen is even better represented than in DS 4. In LALU13, the conifer species become eclipsed by the increased settlement-related introduction of herbaceous pollen. The pollen analysis from the settlement of Luokesa 1 by Motuzaite-Matuzevičiūtè (2007; only four horizons) also shows a higher proportion of conifers, but with fewer grassland types and settlement indicators. However, the Pinus forests presumably did not grow in extent; it is possible that the increasing opening of the landscape favoured the aerial transport of Pinus pollen. Fields of cereals and grasslands are more clearly represented. In general, the landscape appears to have become more open. The uppermost pollen horizon rich in tree pollen may be interpreted as a transgression (flooding) phase, because the pollen spectrum resembles the pollen spectra of the lake marl.
Even if the conifer pollen is proportionally depressed in the diagram by the high amount of cereal pollen in DS 6, we can expect that a woodland vegetation dominated by Pinus sylvestris was still extant in the wider surroundings of the settlement. The slightly raised values for Artemisia combined with Centaurea jacea, C. scabiosa and further NAP indicate the presence of grassland, while Filipendula points to wetlands and wet meadows in the lakeside area. On the basis of the diagrams, it is however impossible to estimate how extensive the clearance was in reality. Nor can we confirm the existence of drier and cooler weather conditions towards the end of the settlement phase, combined with dense forests, as postulated by Motuzaite-Matuzevičiūtè (2007).

Lake levels, hiatuses and environmental conditions prior to the establishment of the L1

The area that was later settled stood under water at least from the Late Atlantic period, causing the formation of lake marl. Deposits earlier than those of the Atlantic period were not reached in the sampling. The two AMS dates of the early Subboreal (4,855 BP, 3710-3630 cal BC) and 4,785 BP, 3650-3510 cal BC) are located only 40 and $30 \mathrm{~cm}$ respectively under the cultural layer but are some 2,500 years older. Assuming a continuous rate of sedimentation, at least $1.25 \mathrm{~m}$ of lake marl should have accumulated in this time span (Wick and Rösch 2006). Recent experiments in Lake Arendsee in northern Germany gave an even higher average sedimentation rate of $5 \mathrm{~mm}$ per year, although this involved widely different rates of sedimentation, depending, among other factors, on the topography of the lake bed (Scharf et al. 2009). Even though we cannot transfer these recent findings onto the sedimentation sequence of Lake Luokesa, it seems highly likely that the low thickness of sediments there indicates that parts of the sediments under the cultural layers are missing. We must assume a hiatus estimated to have lasted at least 1,000 years.

This hiatus may have emerged due to low lake levels documented in Lithuania (Antanaitis-Jacobs et al. 2002; Kabailienè 2006b). No lake marl accumulated on the peninsula that was settled later, or the lake marl deposits were washed away during the lowering of the lake level. As the peninsula falls away towards the deeper lake basin, it is not inconceivable that layers slid off. The LALU104 core was nevertheless taken some $40 \mathrm{~m}$ from the edge of the peninsula.

The pollen curves of the L1 diagrams (DS 1 and DS 2) follow a steady pattern in the Atlantic and Subboreal periods up to a few $\mathrm{cm}$ below the cultural layer and show no hiatus. A certain amount of homogenisation of the pollen spectra through smaller shifts in the layers is not 
excluded. But, as pollen diagrams from the wider region demonstrate, there is no evidence for major changes in the vegetation at this time, a situation that is in accordance with our observations. This makes the identification of a hiatus more difficult (Stančikaitè et al. 2002, 2004).

There are indications of a hiatus only in the palynological examination of the sediments at the transition from the lake marl to the cultural layer (DS 3) carried out at 1 or $2 \mathrm{~cm}$ intervals, a little below the cultural layer. The curves that oscillate strongly from horizon to horizon consistently in all five diagrams suggest the existence of sedimentary conditions changing repeatedly and over a short time. A general decline in Picea and a marked increase in Betula are visible in all the diagrams, and in three diagrams an increase in Alnus is also observable. This could be an indication that the lake level was getting lower and that the settlement was emerging on the shore of the lake. The very high pollen concentrations and the widely oscillating curves of the vesiculate pollen of Pinus and Picea suggest that the site was located in an area of alluviation of the shore. A further indication is provided by the somewhat greater presence of pollen of aquatic plants. The low pollen concentrations for the lake marl recorded in samples 6 (LALU13) and 8 (LALU15) at the limit of DS 2 point to poor preservation conditions, which may well have been caused by the layers being temporarily dry. The lowest samples from the cultural layers also exhibit horizons that are poor in pollen in all 4 diagrams, further indicating that the layers were drying out. It is likely that these fluctuating and low lake levels resulted in hiatuses. Dropping water levels are also proved in the second half of Subboreal in Lakes Duba and Pelesa (Šinkūnas et al. 2005). The presence of a hiatus a little below the cultural layer, at the transition from DS 2 to DS 3, is thus documented by pollen analysis in all diagrams. It is possible that this hiatus encompasses the entire time span estimated above to have lasted some 1,000 years, or at least its later part, and it is to be assigned to the middle or late Subboreal. A number of lakeshore settlements in Central Europe have produced evidence of hiatuses located below their cultural layers (Liese-Kleiber 1976, 1985; Haas and Magny 2004). The sequences of sediments in littoral milieus are however likely to be far more complex than those we can elicit from pollen diagrams.

Lake levels, hiatuses and environmental conditions at the time of L1

After the drop in water levels in the Subboreal and the hiatus proposed here (DS 2/DS3), the peninsula was left in the alluviation zone of the shore area. The surface of the lake marl was left free of water and dried out at certain times, as for example immediately prior to the settlement episode. The pollen spectra at the base of the cultural layer produce evidence of the conditions prevailing just before and at the time of the establishment of the settlement.

Pollen from aquatic plants is recorded in the diagrams from Luokesa most often at the transition between the lake marl and the cultural layer (DS 3/DS 4). It seems that the settlement lay only for a limited time in the vicinity of the belt of aquatic plants that grew in shallow water (DS3). Reed or sedge belts did not become established locally, as pollen of Cyperaceae and wild grasses in which Phragmites is subsumed exhibit only low values.

In the lower part of the cultural layer (DS 4) certain aquatic plants appear, and the good preservation of the pollen also points to a permanently damp environment. It may be possible to identify seasonally deposited layers on the basis of the pollen spectra, as has been shown on Lake Constance in Switzerland (Brombacher and Hadorn 2004). But this was not the case here, and a certain amount of mixing of the sediments through wave action or through human activity is likely. In LALU15 (sample 27) and LALU13 (sample 18) the peaks of Pinus and the high pollen concentration could point to alluviation in the shore area; a short hiatus may be a possibility here.

A phase of desiccation of the sediment, visible in both cultural layer diagrams, is observable at the upper limit of DS 4 (LALU15: samples 38 and 42, LALU13: samples 28 and 29). The evidence for this is comprised of an increase in Alnus, Betula and Corylus pollen, as well as higher values for particularly corrosion-resistant types such as Tilia and Trifolium pratense-type (Burga and Perret 1998), as well as low pollen concentrations. The sediment is sandy and hence an accumulation of sand brought by water is possible. Immediately above that the NAP increase abruptly, especially that of Cerealia. The phase of drying up of the sediments, combined with the sudden growth of the pollen curve, suggests that a short hiatus is likely. In LALU4 the concentrations and preservation of the pollen in DS 4 is markedly worse than that in LALU15 and LALU13, suggesting an intermittent phase of desiccation. It is possible that this is due to the location of the core, which was taken slightly further towards the open lake (see Fig. 3).

In the section above (DS 5) there is almost no pollen of aquatic plants indicating the presence of open water. However the pollen preservation is good, implying a permanently damp depositional milieu. The pollen spectrum is very high in NAP caused by the accumulation of material through human and livestock activity. Moreover, the settlement was not located in a sedge belt. The vegetation of the lakeside area is represented far more by the occurrence of Filipendula, Mentha and Salix. Another indication that water levels fluctuated is observable in the uppermost part of DS5, Pinus and Picea having higher values in both 
diagrams (LALU15 sample 68; LALU13 sample 60). The pollen spectrum is similar to that of the lake marl and indicates flooding.

Fluctuations in the water level are also visible in the upper part of the cultural layer (DS 6). The charcoal content of LALU15 (sample 76) is particularly high and the pollen concentration is very low, which could indicate fire, desiccation and a hiatus. The material above this section is partly disturbed, sandy and possibly recent (no pollen analysis was undertaken).

The pollen analysis indicates that generally damp conditions prevailed on the settlement site, interrupted by short periods of complete desiccation, suggesting that there were short-lived phases of fluctuating lake levels. It is also conceivable that episodes of flooding from streams in the hinterland occurred over the short term, but this is not demonstrated by the pollen diagrams and is unlikely to have happened, given the location of the settlement on the peninsula. The Subatlantic, which had more rainfall and was warmer than today, is generally characterised by higher lake levels once again (Kabailiene 2006b). The settlement of L1 was flooded too, as shown by the sediments above the cultural layer, but it is not possible to determine when this took place or whether this flooding was the cause of the site's abandonment.

\section{Provenance of the material in the cultural layer of L1}

The pollen evidence provides insights into the provenance of materials that were brought to the settlement. As described above, the pollen spectra of cultural layers are composed of two elements, the air-borne or water-borne natural pollen rain and the pollen that reached the settlement through various human and animal actions (HeitzWeniger 1978; Ammann and Liese-Kleiber 1980; Richard 1993). We assume that the natural pollen rain that reached the L1 cultural layer is roughly similar to that of the underlying lake marl. This refers mainly to the arboreal pollen and to the pollen of wild grasses, since these are anemophilous. But when it comes to the provenance of organic material in cultural layers, the air-borne pollen rain has little to contribute, and we have to draw our conclusions from pollen brought in by people and domestic animals. The high values for cereals indicate that grain was harvested ripe and brought to the settlement for threshing. Being autogamous (self-pollinating), the pollen grains remain in the ears of cereals and are only freed by threshing. Such threshing remains with cereal pollen then become embedded in cultural layers together with pollen deriving from weeds of the field. At L1 it is highly likely that pollen of Brassicaceae is representing Camelina, which is very frequently found in the form of macroremains (Pollmann 2014). The rich spectrum of pollen of grassland species suggests that fresh or dried grass was brought to the settlement as fodder. The Alnus woodland on the edge of the lake and the wet meadows were a further source of material. Finally spores of Polypodiaceae (ferns) as well as pollen from Sambucus (elderberry) and Viscum (mistletoe), probably gathered with moss from the forest, also ended up in the cultural layer.

Dung constitutes a further component, and it is documented in the cultural layer of L1. Cattle and sheep/goat dung has been studied in the context of a number of Central European cultural layers (Akeret et al. 1999; Rösch 2002; Haas 2004; Kühn and Hadorn 2004; Haas and Wahlmüller 2010; Kühn et al. 2013). The 4 dung samples from the L1 (LALU15) correspond to the findings of these studies, exhibiting in particular extremely high pollen values for certain taxa. Moreover only a few species are represented, which is typical of sheep/goat coprolites as opposed to cattle dung (Kühn and Hadorn 2004). When comparing the dung pollen spectra with the pollen spectra from the same horizon of the LALU15 diagram, considerable differences come to light (see diagram LALU15-Cop, Fig. 10). The cultural layer sample has a very diverse pollen spectrum in contrast to that of the dung. Consequently, the cultural layer cannot only represent a collection of dung (Haas and Wahlmüller 2010); instead material was introduced into the settlement in other ways. Moreover, some of the pollen spectra of the cultural layer strongly dominated by one pollen type could reflect the remains of dung that is no longer identifiable. Sample 11 (Fig. 10) strikingly resembles the spectrum of the corresponding horizon; it is therefore doubtful whether this sample represents dung.

\section{Human impact in the Luokesa region}

It is not possible to directly estimate the extent of clearances and the size of cultivated plots on the basis of NAP percentages in the diagrams referring to cultural layers (on-site diagrams), since a great deal of pollen reached these layers through human action. Off-site diagrams, from which it may be possible to carry out such an exercise, unfortunately do not exist for the Luokesa region. Nevertheless the pollen diagrams from the cultural layer provide certain indications concerning human impact. The spectrum of pollen types present in the cultural layer can be interrogated qualitatively in terms of this human impact because it gives an indication of what plant communities grew in the vicinity of the settlement. The larger the number of species in the plant community is, the more important its extent.

In the lake marl below the cultural layer, i.e. in the Subboreal (DS 2), there are hardly any indicators of clearance. It is only in DS 3 that the NAP from all ecological groups increase, suggesting that people were already living in the area and clearing woodland before the 


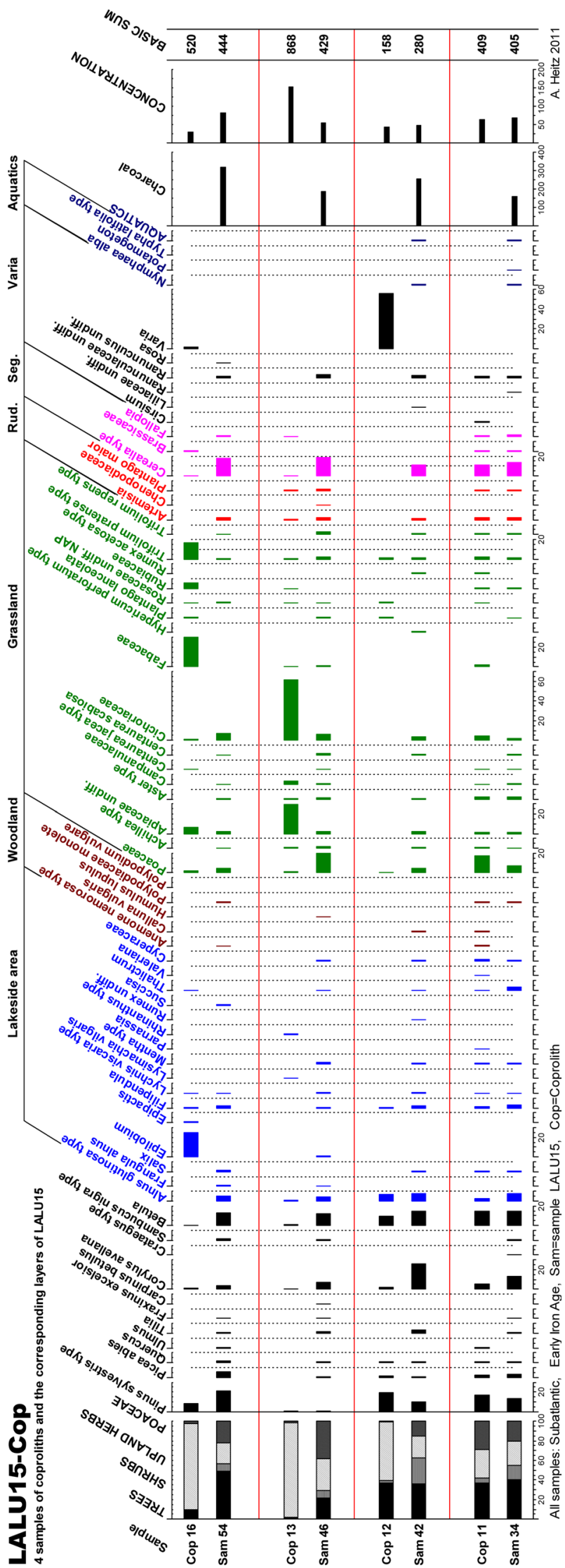

4Fig. 10 Pollen bar diagram, Lake Luokesa 15, coprolites and corresponding cultural layers

establishment of L1. In the pollen diagrams of DS 3 it is mainly wind-borne pollen, such as that of wild grasses, Plantago and Artemisia that is present, and only a few isolated cereal pollen grains are recorded. That riparian woodland grew on the lakeshore is more clearly attested by the presence of Alnus pollen. Betula exhibits higher values too and probably spread on newly cleared land or possibly in lakeshore woodland.

Both diagrams (LALU13, LALU15) show that the upper part of the cultural layer is rich in species of weeds accompanying cultivation (Segetalia), together with high values of cereal pollen, suggesting that the fields expanded. Likewise, in the upper part of the cultural layer the diversity of grassland plants increases slightly, which suggests an expansion of pastures. This points to a stronger intervention in the original vegetation. However, the ruderal plants (Ruderalia), which are light- and nutrient-loving species, are well represented but do not show a change from the lower to the upper part of the cultural layer. If the time of settlement is as short as assumed, this is not astonishing. The transformation of the vegetation cover was not only due to people but also to water levels. The shore plants, especially the trees and shrubs Alnus, Salix and Betula, most probably benefited from the lowering of the lake level and the freeing up of its banks. At the same time some herbaceous species, i.e. the lakeside species, were better able to spread in the clearings on the shore.

As for grazing areas and seasons, the analysis of the 4 dung samples (Fig. 10) produced the following result: each of the 4 samples reflects different grazing areas in different seasons, a situation that has also been documented in Switzerland (Haas and Hadorn 1998). The lowest sample, Cop11, indicates that animals grazed on meadows or arable land in early summer (Betula, Cerealia, Poaceae). The sample Cop12 reflects grazing in lakeshore woodlands in spring (Alnus, Betula); Cop13 derives from meadows grazed in high summer (Apiaceae, Cichoriaceae) while Cop16 is indicative of water meadows grazed in summer (Epilobium, Fabaceae). This pattern also shows that livestock was present in the settlement during the growth season. However, pollen spectra of winter fodder, as found in some dung samples in the settlement of Arbon Bleiche 3 in Switzerland (Haas 2004; Kühn and Hadorn 2004), were not attested in the 4 Luokesa samples.

Comparison of the pollen diagrams from L1 with pollen diagrams from other contemporary settlements

Through lack of investigations of cultural layers there are hardly any diagrams comparable to those of L1 in the 
literature of Lithuania. The two diagrams from the archaeological sites of Zemaitiske 2 and Turlojiske do not contain any cultural layers with organic material (Antanaitis-Jacobs et al. 2002). Moreover, the dating of the cultural layer at Zemaitiske 2 is ambiguous, indeed pollenanalytical and archaeological indications do not coincide. The two diagrams can therefore only give a general idea of the overall development of the vegetation in the Late Holocene, as repeatedly documented (Kabailiene 2006a, 2010). In addition, they show that the landscape was opening during the Subboreal and the Subatlantic. The latter period is also the period in which an opening of the landscape took place at Luokesa. The investigations at the lakes of Wigry and Mazuria in northeastern Poland also do not represent cultural layers; there are only off-site diagrams (Filbrandt-Czaja 2000; Wacnik 2009). The diagram of Wigry lake is well radiocarbon dated, and although it shows human impact elsewhere, hardly any is seen within the EIA (Kupryjanowicz 2007; for more recent data from the Masurian lakes see Wacnik et al. 2014).

A LBA cultural layer represented by a sediment fill in a wooden structure of the settlement of Bruszczewo II located on a former oxbow-lake south of Poznan in western Poland was investigated by Haas and Wahlmüller (2010). Although the settlement site is far from L1 and located in a different phyto-geographical territory, the anthropogenic indicators in the pollen diagram are the same. Plantago lanceolata, P. major, Polygonum aviculare, Artemisia, Chenopodiaceae and Cichoriaceae show high values and indicate land clearing activity contemporary with L1. In contrast to $\mathrm{L} 1$, the rather low cereal pollen values obtained (less than $10 \%$ ) suggest that the threshing area was located at some distance from the settlement.

In Central Europe too there are few lakeshore settlements dated to the LBA and EIA, in contrast to the Neolithic period. The results of pollen analyses carried out at the former sites show in general that land clearances and meadows expanded compared to the Neolithic (Haas and Hadorn 1998; HeitzWeniger 1978; Gauthier and Richard 2009; Laine et al. 2010; Wiemann et al. 2013). Cereal pollen tends to fade somewhat into the background in this late phase of lakeshore settlements and exhibits consistently lower values than those present in Neolithic settlements. This does not necessarily mean that cereal fields became smaller; in general, the landscape appears to have become more open. The investigations at L1 do not contradict this model.

In off-site diagrams from Central Europe, a climatic deterioration after $800 \mathrm{cal} \mathrm{BC}$ is frequently documented. In parallel with the flooding of the lake dwellings a decline in anthropogenic indicators is visible (van Geel et al. 1996; Haas and Hadorn 1998; Burga et al. 2001). However, there is also evidence of an increase in anthropogenic indicators and a massive decline in tree pollen at some locations on both sides of the Alps around 650-400 BC, i.e. during the Iron Age (Hallstatt D) (Tinner et al. 2003) which corresponds to the period of L1. Along with cultural factors, changing climate and geographically unsynchronised fluctuating lake levels may well have caused the permanent abandonment of the lakeshore settlements.

\section{Conclusions}

The history of the woodland vegetation encompasses here the period spanning from the Late Atlantic (ca. 6,000 BP, ca. $4900 \mathrm{cal}$ BC) to the early Subatlantic. Coniferous forests were dominant in the late Atlantic and Subboreal, with abundant Pinus and some Picea. The low NAP (Artemisia, Poaceae) indicate mostly dense forest vegetation. The curves for tree, shrub and herbaceous pollen hardly oscillate until just below the cultural layer accumulation and hence point to stable conditions. Alnus woodland spread along the lakeshore before the beginning of settlement, most probably as a result of a lowering of the lake level. Whether Betula also grew in the damp shore area or whether it spread as a pioneering species on newly available land remains an open question. The coniferous forest became more open during the period of occupation of the settlement in the Subatlantic and mixed deciduous woodland increased. The proportions of all pollen types, which now oscillate widely, indicate that conditions were disrupted by human impact as well as by fluctuations in the lake level.

Water plants did not grow right next to the settlement Luokesa 1, and extensive reed beds did not surround it. Plants of wet meadows, Alnus and perhaps Betula trees grew on the shore of the lake at some distance from the settlement. Grassland and arable land became significant only once the cultural layer began to form and then increased in diversity and extent.

A little below the cultural layer, a hiatus of the order of about 1,000 years is most likely. Before the start of L1 the level of the lake dropped and the settlement was built on dry or damp ground and not above open water. During the occupation period the subsoil generally remained constantly damp. However, three phases of desiccation, as well as an influx of sand, could be detected.

In the cultural layer no continuous sedimentation of material exists, as the material was brought at irregular intervals to the settlement area by humans and livestock. Consequently sometimes high and fluctuating values of NAP such as cereal, Trifolium and Centaurea pollen occur. The results from the dung samples show that the cultural layer was formed partly from manure and partly from other extraneous material. Nevertheless the horizons show constant pollen spectra over several metres horizontally, which is probably indicative of the balancing effect of the water. 
An upper and a lower series of layers are separated by a horizon with low pollen concentration (desiccation, sand influx). This could correspond to two settlement phases; this however is not proven.

Since the relevant material above the cultural layer is absent in the cores, it is not possible to refer to developments after the occupation period. But since lake sediments cover the cultural layer, we can conclude that the lake level rose again and we can assume that it was the cause for the abandonment of the settlement. In the cultural layer itself no signs of change in the pollen curves can be distinguished towards the end of the settlement period. The marked increase in charcoal particles, accompanied by low pollen counts in the two uppermost samples (LALU15, 76 and 78) may however indicate that the settlement was destroyed by fire before it was flooded.

Acknowledgments I thank Lucia Wick for her valuable assistance in determining pollen types as well as for drawing the diagrams. I am also indebted to Willy Tinner, who enabled the chemical processing by Florencia Oberli of the samples in the laboratory of the University of Bern. For stimulating exchange and discussions, I thank Kristin IsmailMeyer, Britta Pollmann, Elena Pranckenaite and Niels Bleicher. Many thanks go to the project managers, Stefanie Jacomet, who contributed many ideas, and Francesco Menotti, who initiated the project. The support of the Swiss National Science Foundation who financed the project 'Understanding human occupation in later prehistoric Europe' (K-13k1-117893) is gratefully acknowledged. For translation into English I thank Patrick Stäuble and Madeleine Hummler.

\section{References}

Akeret Ö, Haas J-N, Leuzinger U, Jacomet S (1999) Plant macrofossils and pollen in goat/sheep faeces from the Neolithic lake-shore settlement Arbon Bleiche 3, Switzerland. Holocene 9:175-182

Ammann B, Liese-Kleiber H (1980) Pollenanalyse: Dokumentation und Auswertung. In: Die neolithischen Ufersiedlungen von Twann, vol. 7. Staatlicher Lehrmittelverlag, Bern

Ammann B, Bollinger T, Jacomet S, Liese-Kleiber H, Piening U (1981) Botanische Untersuchungen, vol 14. Die neolithischen Ufersiedlungen von Twann, Staatlicher Lehrmittelverlag, Bern

Antanaitis-Jacobs I, Stančikaite M (2004) The impact of the economic activities of Stone and Bronze Age populations on their environment according to the archaeobotanical evidence. Lietuvos Archeologija 25:251-266

Antanaitis-Jacobs I, Kisielienė D, Stančikaite M (2002) Macrobotanical and palynological research at two archaeological sites in Lithuania. In: Viklund K (ed) Nordic Archaeobotany-NAG 2000 in Umea, vol. 15. Archaeology and environment VMC KB.C. Umea Universitet, Umea, p 5-21

Behre K-E (1981) The interpretation of anthropogenic indicators in pollen diagrams. Pollen Spores 23:225-245

Bleicher N (2014) Dendrochronological analyses of wood samples from a Late Bronze-Early Iron Age wetland site at Lake Luokesa in Lithuania. Veget Hist Archaeobot 23 (this volume)

Brombacher C, Hadorn P (2004) Untersuchungen der Pollen und Makroreste aus den Profilsäulen. In: Jacomet S, Leuzinger U, Schibler J (eds) Die neolithische Seeufersiedlung Arbon Bleiche 3. Umwelt und Wirtschaft, vol. 12. Archäologie im Thurgau. Amt für Archäologie des Kantons Thurgau, Frauenfeld, p 50-65
Burga CA, Perret R (1998) Vegetation und Klima der Schweiz seit dem jüngeren Eiszeitalter. Ott, Thun

Burga CA, Perret R, Zoller H (2001) Swiss localities of early recognized Holocene climate oscillations-Characterisation and significance. Vierteljahrsschrift Naturforsch Ges Zürich 146:65-74

Czajkowski T, Kompa T, Bolte A (2006) Zur Verbreitungsgrenze der Buche (Fagus sylvatica L.) im nordöstlichen Mitteleuropa. Forstarchiv 77:203-216

Filbrandt-Czaja A (2000) Vegetation changes in the surroundings of Lake Dagł Wielki in the light of pollen analysis. In: Kola A (ed) Studies in lake dwellings of the West Baltic Barrow Culture, Torun, 2000. Uniwersytetu Mikołaja Kopernika, p 89-98

Gauthier E, Richard H (2009) Bronze Age at Lake Bourget (NW Alps, France): vegetation, human impact and climatic change. Quat Int 200:11-119

Girininkas A (2008) The influence of the environment on the human population around Lake Kretuonas during the Stone Age and Bronze Age. Archaeol Baltica 9:15-32

Haas JN (2004) Mikroskopische Analyse von Schaf-/Ziegenkoprolithen. In: Jacomet $\mathrm{S}$, Leuzinger $\mathrm{U}$, Schibler $\mathrm{J}$ (eds) Die neolithische Seeufersiedlung Arbon Bleiche 3. Umwelt und Wirtschaft, vol. 12. Archäologie im Thurgau. Amt für Archäologie des Kantons Thurgau, Frauenfeld, p 351-357

Haas J-N, Hadorn P (1998) Die Vegetations- und Kulturlandgeschichte des Seebachtals von der Mittelsteinzeit bis zum Frühmittelalter anhand von Pollenanalysen. In: Hasenfratz A, Schnyder M (eds) Das Seebachtal. Eine archäologische und paläoökologische Bestandesaufnahme. Archäologie im Thurgau 4, p 221-255

Haas JN, Magny M (2004) Schichtgenese und Vegetationsgeschichte. In: Jacomet S, Leuzinger U, Schibler J (eds) Die neolithische Seeufersiedlung Arbon Bleiche 3. Umwelt und Wirtschaft, vol. 12. Archäologie im Thurgau. Amt für Archäologie des Kantons Thurgau, Frauenfeld, p 43-49

Haas JN, Wahlmüller N (2010) Floren-, Vegetations- und Milieuveränderungen im Zuge der bronzezeitlichen Besiedlung von Bruszczewo (Polen) und der landwirtschaftlichen Nutzung der umliegenden Gebiete. Przemiany środowiska, wegetacji i flory w ramach osadnictwa epoki brązu w Bruszczewie oraz gospodarcze użytkowanie otoczenia osady. Studien zur Archäologie in Ostmitteleuropa, Studia nad Pradziejami Europy Środkowej 6:1-2

Hadorn P (1994) Saint-Blaise/Bains des Dames 1, Palynologie d'un site néolithique et histoire de la végétation des derniers 16000 ans. Archéologie Neuchâteloise 18. Musée Cantonal d'Archéologie, Neuchâtel

Heitz-Weniger A (1978) Pollenanalytische Untersuchungen an den neolithischen und spätbronzezeitlichen Seerandsiedlungen Kleiner Hafner, Grosser Hafner und Alpenquai im untersten Zürichsee (Schweiz). Bot Jb Systematik, Pflanzengesch Pflanzengeogr 99:48-107

Ismail-Meyer K (2014) The potential of micromorphology for interpreting sedimentation processes in wetland sites: a case study of a Late Bronze-Early Iron Age lakeshore settlement at Lake Luokesa (Lithuania). Veget Hist Archaeobot 23 (this volume)

Kabailiene M (1996) Lithuania. Palaeoecological events during the last 15,000 years: regional syntheses of palaeoecological studies of lakes and mires in Europe. Wiley, Chichester

Kabailiené M (1998) Vegetation history and climate changes in Lithuania during the Late Glacial and Holocene, according to pollen and diatom data. PACT 54:13-30

Kabailiene M (2006a) Late Glacial and Holocene stratigraphy of Lithuania based on pollen and diatom data. Geologija 54:42-48

Kabailienė M (2006b) Main stages of natural environmental changes in Lithuania during the Late Glacial and Holocene. Geologija 55:37-47

Kabailiene M (2010) Formation of pollen spectra and interpretation methods. Application to Late Glacial and Holocene history of vegetation in Lithuania. Lambert Acad Publ, Saarbrücken, p 316 
Kabailienė M, Grigiene A (1997) Vegetation and signs of human economic activities in the environs of Lake Kretuonas during middle and late Holocene. Geologija 21:44-52

Kühn M, Hadorn P (2004) Pflanzliche Makro- und Mikroreste aus Dung von Wiederkäuern. In: Jacomet S, Leuzinger U, Schibler J (eds) Die jungsteinzeitliche Seeufersiedlung Arbon Bleiche 3. Umwelt und Wirtschaft, vol. 12. Archäologie im Thurgau. Amt für Archäologie des Kantons Thurgau, Frauenfeld, p 327-350

Kühn M, Maier U, Herbig C, Ismail-Meyer K, Le Bailly M, Wick L (2013) Methods for the examination of cattle, sheep and goat dung in prehistoric wetland settlements with examples of the sites Alleshausen-Täschenwiesen and Alleshausen-Grundwiesen (around cal 2900 BC) at Lake Federsee, south-west Germany. Environ Archaeol 18:5-19

Kupryjanowicz M (2007) Postglacial development of vegetation in the vicinity of the Wigry Lake. Geochronometria 27:53-66. doi:10.2478/v10003-007-0018-x

Laasimer L, Kuusk V, Tabaka L, Lekavicius A (1993) Flora of the Baltic countries, vol. 1. Estonian Academy of Sciences, Tartu

Laine A, Gauthier E, Gracia J-P, Petit C, Cruz F, Richard H (2010) A three-thousand-year history of vegetation and human impact in Burgundy (France) reconstructed from pollen and non-pollen palynomorphs analysis. CR Biol 333:850-857

Liese-Kleiber H (1976) La fouille du Garage Martin 1973. Pollenanalytische Untersuchungen. Cahiers d'Archéologie Romande 8:145-157

Liese-Kleiber H (1985) Pollenanalysen in der Ufersiedlung Hornstaad-Hörnle I. Mathefte Vor- Frühgesch Bad-Württ 6

Mangerud J, Andersen ST, Berglund BE, Donner JJ (1974) Quaternary stratigraphy of Norden, a proposal for terminology and classification. Boreas 3:109-128

Menotti F, Baubonis Z, Brazaitis D, Higham T, Kvedaravičius M, Lewis H, Motuzaite G, Pranckenaite E (2005) The first lakedwellers of Lithuania: Late Bronze Age pile settlements on Lake Luokesas. Oxford J Archaeol 24:381-403

Moore PD, Webb JA, Collinson ME (1991) Pollen analysis, 2nd edn. Blackwell, London

Motuzaite-Matuzevičiūte G (2007) Living on the lake and farming the land. Archaeobotanical investigation on Luokesai I lake dwelling site. Lietuvos Archeologija 31:123-138

Pollmann, B (2014) Environment and agriculture of the transitional period from Late Bronze to Early Iron Age in the Eastern Baltican archaeobotanical case study of the lakeshore settlement Luokesa 1 (Lithuania). Veget Hist Archaeobot 23 (this volume)

Pranckenaite E (2010) Freshwater archaeology in Lithuania: investigations and prospects. Archaeol Baltica 14

Pranckènaite E (2011) Prehistoric archaeology of wetlands in Lithuania. In: Pranckenaite E (ed) Wetland settlements of the Baltic. Vilnius

Pranckenaite E (2014) Living in wetlands in the south-eastern Baltic Sea region during the Late Bronze-Early Iron Age: the archaeological context of the Luokesa lake-dwellings. Veget Hist Archaeobot 23 (this volume)

Richard H (1993) Palynological micro-analysis in Neolithic Lake dwellings. J Archaeol Sci 20:241-262

Roering HW (1999) Die Forstwirtschaft Litauens. Arbeitsbericht des Instituts für Ökonomie Bundesforschungsanstalt für Forst- und Holzwirtschaft Hamburg 99/3

Rösch M (2002) Ziegenkot aus den Horgener Schichten von Ludwigshafen-Seehalde, Gde. Bodman-Ludwigshafen Kreis Konstanz. Archäol Ausgrab Bad-Württ 2001:49-51

Saarse L, Poska A, Veski S (2010) Is there a relationship between crop farming and the Alnus decline in the eastern Baltic region? Veget Hist Archaeobot 19:17-28

Scharf BW, Boehrer B, Buettner O, Kopsch C, Niessen F (2009) Local variability of sedimentation rate in Lake Arendsee, Germany. Limnologica 40:97-101. doi:10.1016/j.limno.2009.10.004
Šeirienė V, Kabailienė M, Kasperoviciene J, Mazeika J, Petrosius R, Paskauskas R (2009) Reconstruction of postglacial palaeoenvironmental changes in eastern Luthiana: evidence from lacustrine sediment data. Quat Int 207:58-68

Šinkūnas P, Stančikaitė M, Šeiriene V, Kisielienė D, Barzdžiuvienė V, Blažauskas N (2005) Environmental changes in the Ula and Katra upper reaches during the last 14000 years. Acta Zool Lituanica 15:173-178

Stančikaite M, Kabailiene M, Ostrauskas T (2002) Environment and man around Lakes Duba and Pelesa, SE Lithuania, during the Late Glacial and Holocene. Geol Q 46:391-409

Stančikaitė M, Milkevicius M, Kisielienè D (2003) Palaeoenvironmental changes in the environs of Zadeikiai bog, NW Lithuania, during Late Glacial and the Holocene according to palaeobotanical and ${ }^{14} \mathrm{C}$ data. Geologija 43:47-60

Stančikaite M, Kisielienè D, Strimaitienè A (2004) Vegetation response to the climatic and human impact changes during the post Glacial: case study of the marginal area of Baltija Upland, NE Lithuania. BALTICA 17:17-33

Stančikaitė M, Baltrunas V, Šinkūnas P, Kisielienè D, Ostrauskas T (2006) Human response to the Holocene environmental changes in the Birzulis Lake region, NW Lithuania. Quat Int 150:113129. doi:10.1016/j.quaint.2006.01.010

Stančikaitè M, Šinkūnas P, Risberg J, Šeirienè V, Blažauskas N, Jarockis R, Karlsson S, Miller U (2009a) Human activity and the environment during the Late Iron Age and Middle Ages at the Impiltis archaeological site, NW Lithuania. Quat Int 203:74-90

Stančikaite M, Daugnora L, Hjelle K, Hufthammer AK (2009b) The environment of the Neolithic archaeological sites in Sventoji, Western Lithuania. Quat Int 207:117-129. doi:10.1016/j.quaint. 2009.01.012

Stockmarr J (1971) Tablets with spores used in absolute pollen analysis. Pollen Spores 13:615-621

Tinner W, Lotter AF, Ammann B, Conedera M, van Leeuwen JFN, Wehrli M (2003) Climatic change and contemporanous land use phases north and south of the Alps 2300 BC to 800 AD. Quat Sci Rev 22:1,447-1,460

Van Geel B, Magny M (2002) Mise en évidence d'un forçage solaire du climat à partir de données paléoécologiques et archéologiques: la transition Subboréal-Subatlantique. In: Richard H, Vignot A (eds) Equilibres et ruptures dans les écosystèmes depuis 20000 ans en Europe de l'Ouest, vol. 3. Presses Universitaires Franc-Comtoise 831. Collection Annales Litteraires 730. Série Environnement, Société et Archéologie, p 107-122

Van Geel B, Buurman J, Waterbolk HT (1996) Archaeological and palaeoecological indications of an abrupt climate change in the Netherlands, and evidence for climatological teleconnections around 2650 BP. J Quat Sci 11:451-460

Wacnik A (2009) From foraging to farming in the Great Mazurian Lake District: palynological studies on Lake Milkowskie sediments, northeast Poland. Veget Hist Archaeobot 18:187-203. doi:10.1007/s00334-008-0196-0

Wacnik A, Kupryjanowicz M, Mueller-Bieniek A, Karczewski M, Cywa K (2014) The environmental and cultural contexts of the late Iron Age and medieval settlement in the Mazurian Lake District, NE Poland-combined palaeobotanical and archaeological data. Veget Hist Archaeobot 23 (this volume)

Wick L, Rösch M (2006) Von der Natur- zur Kulturlandschaft, Ein Forschungsprojekt zur jungsteinzeitlichen und bronzezeitlichen Landnutzung am Bodensee. Denkmalpflege in Baden-Württemberg 36:225-233

Wiemann P, Kühn M, Heitz-Weniger A, Stopp B, Jennings B, Rentzel P, Menotti F (2013) The end of a lake-dwelling: a multidisciplinary approach to the Late Bronze Age lakeside settlement of Zurich-Alpenquai. J Wetland Archaeol 12:58-85 